\title{
Evaluation of toxicity of Deepwater Horizon slick oil on spat of the oyster Crassostrea virginica
}

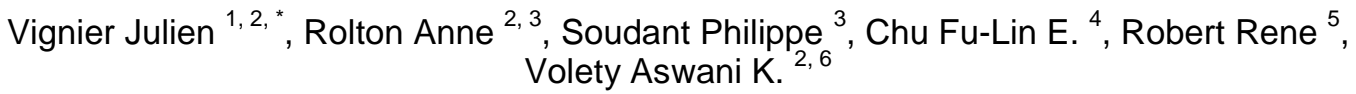

${ }^{1}$ Cawthron Inst, 98 Halifax St East, Nelson 7010, New Zealand.

${ }^{2}$ Florida Gulf Coast Univ, Dept Marine \& Ecol Sci, Coll Arts \& Sci, Ft Myers, FL 33965 USA.

3 IUEM UBO, Lab Sci Environm Marin, UMR LEMAR 6539, Technopole Brest Iroise, F-29280 Plouzane, France.

${ }^{4}$ VIMS, Dept Aquat Hlth Sci, Coll William \& Mary, Gloucester Point, VA 23062 USA.

${ }^{5}$ IFREMER, Unite Littoral, Ctr Bretagne ZI Pointe Diable, CS 10070, F-29280 Plouzane, France.

${ }^{6}$ Univ North Carolina Wilmington, Bear Hall 146,601 S Coll Rd, Wilmington, NC 28403 USA.

* Corresponding author : Julien Vignier, email address : julien.vignier@cawthron.org.nz

\begin{abstract}
:
The 2010 explosion of the Deepwater Horizon (DWH) oil rig generated the largest marine oil spill in US history with millions of barrels of crude oil released in the Gulf of Mexico (GoM). The eastern oyster, Crassostrea virginica, is an ecologically and economically important species in the northern GoM. Due to its biological characteristics (sessile, filter feeding), juvenile oysters may have been affected. This study investigated the effects of surface-collected DWH oil prepared as high-energy wateraccommodated fraction (HEWAF) on the survival of 2-month-old oyster spat, and evaluated the potential impacts of HEWAF on particle clearance rate and spat tissue. Exposure of oysters to a range of oil/HEWAF (0-7-66-147-908-3450 mu g tPAH50 (sum of 50 polycyclic aromatic hydrocarbons) L-1) resulted in non-dose-dependent mortalities and reduced clearance rates of algal food (Tisochrysis lutea). A morphometric study of the digestive tubules (DGTs) indicated a dose-dependent response to oil exposure on lumen dilation, on epithelium thinning of the DGT, and a significant change in DGT synchrony (LOEC $=66$ mu g tPAH50 L-1). This finding suggests that structural changes occurred in the digestive gland of exposed oysters most likely due to an oil-related stress. In addition, histological observations showed that tissues in contact with HEWAF (gills, palp, connective tissue, digestive gland) were adversely impacted at $>=7 \mathrm{mu} \mathrm{g} \mathrm{tPAH50} \mathrm{L-1,} \mathrm{and} \mathrm{exhibited} \mathrm{pathological} \mathrm{symptoms} \mathrm{typical} \mathrm{of} \mathrm{an}$ inflammatory response (e.g., hemocyte diapedesis and infiltration, syncytia, epithelium sloughing).
\end{abstract}

Keywords: Oyster spat, Deepwater Horizon oil, Sublethal, Tissue, Inflammatory response, Histopathology 


\section{Introduction}

On April 20 2010 , the explosion at the Deepwater Horizon (DWH) oil drilling rig located 50 miles southeast of the Louisiana Coast in Mississippi Canyon Block 252 (28 $\left.55^{\prime} 12^{\prime \prime} \mathrm{N}, 88^{\circ} 23^{\prime} 14^{\prime \prime} \mathrm{W}\right)$, led to the largest marine oil spill in United States history (Carriger \& Barron, 2011; National Commission, 2010). Until the well was capped and the flow finally stopped, 87 days after the DWH oil rig sank, several million barrels of light Louisiana crude oil were released into the Gulf of Mexico (GoM) (U.S District Court, 2014; 2015). The escaping oil created a deep sea "cloud" or "plume", and a surface slick covering up to $112,000 \mathrm{~km}^{2}$ of the Gulf waters (Boesch, 2014; ERMA, 2015)]. The coastal extent of the spill was from Louisiana to Florida, with at least 2,113 km of shoreline visibly oiled (Nixon et al., 2015).

Petroleum hydrocarbons or crude oil constituents are one of the most common contaminants released into the marine environment: some of them are of particular concern due to their high chemical stability, low solubility, low degradation, and lipophilic nature. Although oil spills represent a small fraction of the total crude oil discharge into the sea, they have acute and long term impacts on marine ecosystems, including effects from physical damage (physical contamination and smothering) and toxicity from chemical compounds (NRC, 2003). Polycyclic aromatic hydrocarbons (PAHs) are considered to be the most acutely toxic components of crude oil (Neff, 1985; Neff \& Stubblefield, 1995). Given their lipophilic nature, these contaminants can bind to particulate organic matter, sediment and microalgae, thus entering the food web (Graham et al., 2010; Lee et al., 1978). Sedentary, benthic filter-feeding organisms such as oysters have an enormous filtration capacity and are particularly effective in taking up hydrocarbons via filtration (Newell, 2004). Following ingestion of hydrocarbons, oysters may accumulate high concentrations within their tissues and may be susceptible to the negative effects of these contaminants. For this reason, bivalve mollusks, such as oysters and mussels, are employed on a world-wide scale as sentinel organisms to monitor 
47

concentrations of contaminants in estuarine and coastal environments (Farrington et al., 1983;

48 O’Connor \& Lauenstein, 2006).

49 The Eastern oyster (Crassostrea virginica) is one of the most commercially important shellfish 50 species in the GoM, representing about $\$ 74$ million in landings value in coastal regions of the northern Gulf for 2012 (NMFS, 2012). In addition to its economic value, it is also an ecologically vital species. Oyster reefs provide food, shelter and habitat for many fish and shellfish species, improve water quality, stabilize bottom areas, and influence water circulation patterns within estuaries (Coen et al., 2007; Newell, 2004; Wells, 1961). Although the location of the spill was in deep water, currents carried the oil to shallow coastal waters and estuaries, which are spawning and nursery grounds for many marine species, including oysters. In the North of the GoM, two peaks in settlement of $C$. virginica occur in early and late summer (Supan, 1983). Given the time of the DWH spill, newly settled spat and juveniles of $C$. virginica are thus likely to have been exposed to DWH crude oil and associated PAHs. The physiological and ecological effects of environmental stress are numerous. While the ultimate endpoint of stress is mortality, sub-lethal effects may interfere with normal metabolic processes of the animals, thus increasing expenditure of energy reserves at the expense of growth, survival and ultimately reproduction and recruitment (Capuzzo, 1996).

Given their role of sentinel in coastal environment, bivalve species have the capacity to survive in highly polluted waters, despite the fact that pollutant levels often overload the normal physiological mechanism of biotransformation or detoxification present in the cell (Gilewicz et al., 1984; Moore, 1985). Exposure to some petroleum hydrocarbons can cause alterations in the condition of certain molluscs, by reducing the feeding efficiency of the animals (Axiak \& George, 1987; Barszcz et al., 1977; Galtsoff et al., 1935). As a result, variations in clearance rates of oil-exposed oysters may influence the degree of assimilation and exposure of specific tissues, and, subsequent damage. After long-term and sub-lethal exposure to petroleum hydrocarbons, vacuolization and atrophy of the digestive cells leading to a thinning of the digestive epithelium and subsequently to an increase in tubule lumen size have been reported for molluscs (Cajaraville et al., 1989; Lowe et al., 1981; 
Widdows et al., 1982). In addition, a loss of the normal synchrony of the digestive cells of mussels

74 exposed long-term to oil has been found, to a point where almost all the tubules exhibited a similar 75 appearance (i.e. reconstituting stage) (Lowe et al., 1981). To avoid some of the subjectivity 76 associated with descriptive histology, quantitative techniques, such as stereology and morphometric 77 analysis, have been employed to measure alterations in cells following contaminant exposure (Cajaraville et al., 1989; Lowe et al., 1981). Accordingly, in the present study, morphometric analyses were employed to quantify alterations on the digestive tubules of oil-exposed $C$. virginica.

Histopathological changes are powerful indicators of prior exposure to environmental stressors, especially xenobiotics, and histopathology is often seen as the easiest method for assessing both short- and long-term toxic effects in the field (Kim et al., 2006). The long-term effects of oil exposure in oysters collected from the field were studied after the Amoco Cadiz spill and included necrosis, inflammation, and lesions of the digestive tract epithelium, gonads, connective tissue, and gills (Berthou et al., 1987; Neff \& Haensly, 1982). After an exposure to petroleum hydrocarbons, degeneration of epithelial cells in the foot and alimentary canal, activation of mucus secretory cells and inflammatory responses in the gills of the clam Venus verrucosa were observed (Axiak et al., 1988). These studies suggest that after exposure to oil, an inflammatory response will likely occur, mainly located in the gills and the digestive system of exposed bivalves. Studies have also shown evidence that contaminant-stimulated "reactive oxygen species" (ROS) production and resulting oxidative damage may be a mechanism of toxicity in aquatic organisms exposed to pollution (Di Giulio et al., 1989; Livingstone et al., 1989; 2001).

The objective of the present study was to determine the physiological (e.g. clearance rates), tissue (e.g. digestive tubules staging, tubule lumen sizes, inflammatory responses) and biochemical (e.g. lipid peroxidation) responses of $C$. virginica spat exposed to increasing concentrations of highenergy water accommodated fraction (HEWAF) of oil. 
98

99

100

101

102

103

14

15

16

17

18

\section{Material and methods}

\subsection{Preparation of exposure solutions}

Surface oil, also referred to as "Slick A", was collected on July $29^{\text {th }} 2010$, from the hold of barge number CTC02404, which was receiving surface slick oil from various skimmer vessels near the Macondo well, and was delivered under chain of custody (sample CTC02404-02). Slick A incurred significant natural weathering at sea before collection. HEWAF exposure solutions were prepared following a standardized procedure extensively detailed in Vignier et al. (2015). Briefly, two-liters of UV-sterilized and $0.1 \mu \mathrm{m}$-filtered seawater (FSW) were added to a stainless-steel blender pitcher (Waring ${ }^{\mathrm{TM}}$ CB15 commercial food blender) and $4 \mathrm{~g}$ of Slick A were added using a gastight syringe (1:500 dilutions of oil). After blending for $30 \mathrm{~s}$ at low speed, the solution was transferred to a 2-L aspirator bottle and left to settle for at least one hour to allow separation of the solution from residual floating oil. The stock solution $\left(2 \mathrm{~g}\right.$ oil $\left.\mathrm{L}^{-1}\right)$ was obtained by carefully draining the bottom layer of the mixture from the aspirator bottle and used for PAH analysis and test dilutions with FSW. Four liters of stock solution were prepared every other day with fresh oil. The solution was not filtered, and thus contained whole particulate oil in addition to dissolved PAHs.

\subsection{Water quality}

114 Throughout the exposure period, temperature and dissolved oxygen (DO) were monitored daily by 115 means of a Pro ODO optic probe $\left(\mathrm{YSI}^{\mathrm{TM}}\right)$, while salinity and $\mathrm{pH}$ were measured daily using a 116 refractometer (Pentair Aquatic Eco-systems Inc. ${ }^{\mathrm{TM}}$ ) and a "Pinpoint" pH monitor (American Marine 117 Inc. $^{\mathrm{TM}}$ ) respectively. Total ammonia was measured in each treatment, and analyzed using a SEAL 118 Analytical Auto-Analyzer 3. All water quality parameters were measured daily, and from both 119 discarded and fresh exposure solutions. Each exposure chamber was aerated to maintain oxygen 120 levels above $5 \mathrm{mg} \mathrm{L}^{-1}$ and light photoperiod was maintained at 12h: $12 \mathrm{~h}$ using fluorescent lamps.

\subsection{Experimental design}


123 Two month-old single seed oyster spat (mean shell length $\approx 10-15 \mathrm{~mm}$; mean individual dry weight $\approx$ $1240.5 \mathrm{mg}$ ) from the Auburn University shellfish laboratory (Dauphin Island, AL) were used during spring 2013. After reception, oyster spat were gradually acclimated at the experimental hatchery in a flow-through tank for 2 weeks. Using a sump and a submersible pump, seawater was semirecirculated and salinity was gently increased over several days, from its origin (i.e. 20 PSU \pm 2 ) to the local conditions (ambient temperature of $23^{\circ} \mathrm{C} \pm 1$ and salinity of $30 \mathrm{PSU} \pm 2$ ). Oyster were fed ad libitum with Instant Algae/Shellfish Diet ${ }^{\circledR}$ (Reed Mariculture Inc. ${ }^{\mathrm{TM}}$ ) for optimal growth.

\subsubsection{Experiment 1: HEWAF exposure and clearance rate measurements}

Clearance rate (or filtration) measurements were carried out in $600 \mathrm{~mL}$ glass beakers for $24 \mathrm{~h}$ using the unicellular microalgae Tisochrysis lutea (CCMP 1324). Gentle central aeration by means of a glass pipette was provided at $100 \mathrm{~mL} \mathrm{~min}^{-1}$ to each beaker to homogenize exposure solutions. Ten spat per beaker were exposed, in triplicate, to increasing concentrations of HEWAF ranging from 100 to $2000 \mathrm{mg}$ oil $\mathrm{L}^{-1}$. Total PAH content was not quantified in exposure solutions used in the 24-h filtration experiment. As a result, exposure treatments will be referred to as nominal concentrations of HEWAF and expressed in $\mathrm{mg}$ oil $\mathrm{L}^{-1}$. At the start of the exposure, spat were fed ad libitum with 1 billion cells (equivalent to $100 \mathrm{~mL}$ ) of T-lutea per beaker. After thorough mixing, residual algal cells were assessed through the exposure $\left(\mathrm{T}_{0}\right.$ and $\left.\mathrm{T}_{24}\right)$ by taking a $1.5 \mathrm{~mL}$ aliquot from each replicate and then fixing the sample by addition of $100 \mu \mathrm{L}$ of Glutaraldehyde. After thorough agitation, three $10 \mu \mathrm{L}$ subsamples were taken from the fixed aliquots and counted under a microscope using a hemocytometer. Algal cells counts were then averaged for each sampling point and $24 \mathrm{~h}$ clearance rates were determined for each HEWAF condition. To compare different treatments, clearance rates 
145

(CR) were normalized per gram of whole dry tissue weight of oyster, and determined using the following equation, adapted from Coughlan (1969):

$$
\left.C R=(V /(n \times t)) x \ln \left(C_{t i} / C_{t f}\right)\right) / \varpi
$$

148 where "CR" is the clearance rate in $\mathrm{L} \mathrm{h}^{-1} \mathrm{~g}^{-1}$; "V" is the volume of each container in $\mathrm{L}$ (i.e. $0.5 \mathrm{~L}$ ); " $\mathrm{n}$ " 149 is the number of spat; " $\mathrm{t}$ " is the time of experiment in $\mathrm{h}$; " $\mathrm{C}_{t i}$ " and " $\mathrm{C}_{t f}$ " are the initial and final counts 150 of $T$. lutea cells at $t_{i}$ or $t_{f} ; " ~ " \varpi "$ is the mean individual dry weight of spat in $g(\varpi=0.0005 \mathrm{~g})$.

151 We assumed that pumping rate of animal was constant, particle retention was $100 \%$ efficient and the 152 algal concentration was homogenous at all times thanks to aeration.

153 2.3.3 Experiment 2: Acute exposure to HEWAF for 10 days

$154 \quad$ 2.3.3.1 Mortality measurement

155 Single oyster spat were haphazardly distributed at a density of 15 per beaker, in triplicate (5 156 replicates for the control). Gentle central aeration by means of a glass pipette was supplied to each beaker at $100 \mathrm{~mL} \mathrm{~min}^{-1}$. Spat were exposed for 10 days to increasing concentrations of HEWAF ( 0 $10-50-100-500-2000 \mathrm{mg}$ oil $\mathrm{L}^{-1}$ corresponding to $0-7-66-147-904-3450 \mu \mathrm{g}$ tPAH50 L${ }^{1}$ ). This range of doses tested and exposure duration were chosen according to partial mortality results observed during preliminary range finding tests. Exposure was performed in $600 \mathrm{~mL}$ glass beakers filled up with $500 \mathrm{~mL}$ of solution, under static-renewal conditions, with the exposure media renewed every other day (i.e. new fresh stock of HEWAF was prepared every other day). Spat from each beaker were fed daily with $2 \mathrm{~mL}$ of Instant Algae $^{\circledR}$. Every other day, spat were collected on a 2mm stainless steel sieve, and observed using a dissecting microscope for examination of dead spat, measured by their failure to close their valves in seawater. Beakers were cleaned using deionized water and Kim-Wipes ${ }^{\circledR}$, and refilled with new exposure media.

\subsubsection{Histopathological study}


At the start of the experiment and following acclimation, histopathological condition of 26 individual oyster spat was examined (Control Day 0; results presented in Table 2). At the end of the 10 day exposure to HEWAF, 15 spat (excluding dead) from each concentration were randomly selected for histological examination. The number of individuals sampled represented a third of the population. Oyster spat were then fixed in a solution of Davidson's fixative for $48 \mathrm{~h}$ at $4^{\circ} \mathrm{C}$. After rinsing thoroughly with tap water, animals were placed in individual histological cassettes in a solution of 10 $\%$ EDTA $(\mathrm{pH}=7.5)$ for decalcification (Howard et al., 2004). Solution of EDTA was changed every other day during the week of decalcification process. After decalcification and thorough rinsing, spat were transferred to cold $70 \%$ ethanol solution. Following dehydration through an ascending ethanol series, tissues were dealcoholized with xylene using a tissue processor (Shandon Citadel 1000), and embedded in paraffin wax. Sections $(5 \mu \mathrm{m})$ were cut on a rotary microtome (Microm HM325), stained with Harris' hematoxylin and eosin (Winstead, 1995), and examined with light microscopy. A four-level semi-quantitative scale, from 0 to 3, was established to assess the intensity of each histopathological condition observed in the gastro-intestinal system (i.e. hemocyte diapedesis, hemocyte infiltration, mucus infiltration, and hyperplasia of mucus secretory cells). $0=$ no occurrence of the pathological condition was examined in the tissue area; $1=$ light (i.e. covering less than $5 \%$ of the tissue); $2=$ moderate (i.e. covering about $10 \%$ of the tissue); and $3=$ severe (i.e. covering about $25 \%$ of the tissue).

\section{7 b) Morphometric analysis of the digestive tubules}

188 Using an Olympus IX73 inverted microscope equipped with an Olympus DP73 camera and the 189 CellSens image analysis software, digestive tubules were measured at random from histological 190 sections of 6 surviving animals haphazardly selected in each treatment. Morphometric analysis 191 followed a protocol adapted and modified from Cajaraville et al. (1989) and Winstead (1995). 192 Histological cross sections of the digestive gland were divided into 4 fields of observation per 
193

animal. Eight randomly selected tubules from each field (32 total tubules per spat) were measured.

194 Two sets of measurements, internal (luminal) surface and total tubule surface, for each tubule were 195 determined using the CellSens image analysis software, and tubule luminal ratio (luminal 196 surface/total surface) was calculated.

\section{7 c) Grading of digestive tubules}

198 The phasic activity of the digestive gland was assessed by means of a subjective grading of the same tubules selected previously for morphometric measurements. Thus, at least 30 tubules per individual and a minimum of 180 per experimental group (6 oysters) were therefore categorized. Four tubule types were distinguished as described by Cajaraville (1989) (Fig. 1): holding/absorbing (combined as stage I), disintegrating (stage II), reconstituting (stage III), and a fourth tubule type, not related to the digestion process, and named "necrotic" (stage IV). The percentage occurrence of the 4 different tubule types with respect to the total number measured was then calculated.

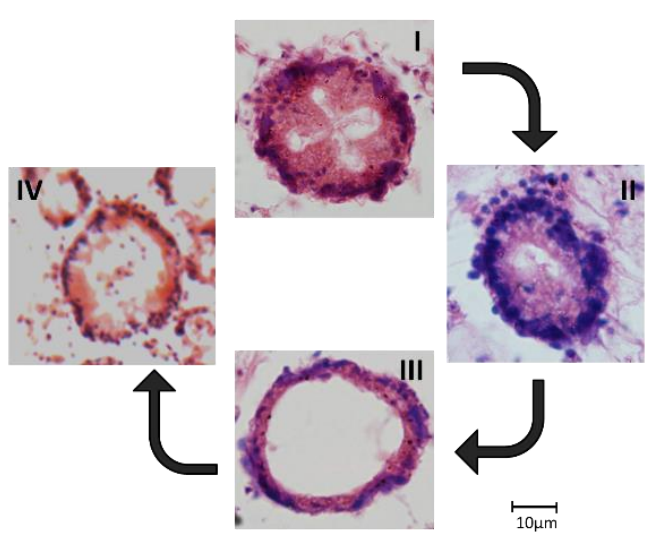

206 Figure 1: Subjective grading of digestive tubules into the 4 different stages observed. I: Absorbing / 207 Holding; II: Disintegrating; III: Reconstituting; IV: Necrotic (sloughing).

\subsubsection{Biochemical analysis (lipid peroxidation assay)}

209 Surviving oysters, which were not processed for histological analyses, were used for lipid 210 peroxidation assay. Lipid peroxides derived from polyunsaturated fatty acids are unstable and 211 decompose to other complex compounds of which malondialdehyde (MDA), a marker for oxidative 
212

stress, is the most abundant by-product. MDA was measured by a spectrophotometric assay using a commercial BIOXYTECH $^{\circledR}$ MDA-586 kit (Oxis Research). The method is based on the reaction of a chromogenic agent, $\mathrm{N}$ methyl-2-phenylindole with MDA at $45^{\circ} \mathrm{C}$. A minimum of $100 \mathrm{mg}$ wet weight of oyster tissue was homogenized by sonication for $15 \mathrm{~min}$ in $990 \mu \mathrm{L}$ of Phosphate Buffer Saline (PBS, $\mathrm{pH}=7.4$ ) and $10 \mu \mathrm{L}$ of Butylated Hydrotoluene (BHT) to avoid intra-assay oxidation. The 217 homogenate was then centrifuged at $10,000 \mathrm{~g}$ for $10 \mathrm{~min}$, and the supernatant $(200 \mu \mathrm{L})$ was added to 218 a mixture of probucol in methanol, N-methyl-2-phenylindole, and hydrochloric acid as indicated in 219 the MDA-586 kit. The reaction was conducted at $45^{\circ} \mathrm{C}$ for $60 \mathrm{~min}$. After centrifugation at $10,000 \mathrm{~g}$ 220 for $10 \mathrm{~min}$, the clear supernatant was transferred into a microtitration plate and the absorbance was measured at $586 \mathrm{~nm}$. A standard curve was established with a solution of tetramethoxypropane (TMP) hydrolyzed during the acid incubation step generating MDA. Results were expressed in $\mu$ mol of MDA per $g$ of wet mass of oyster tissue.

\subsection{Analytical chemistry}

During experiment 2, samples of every preparation of HEWAF (including FSW control, stock solution and dilutions) were collected at the start and before the first exposure solution renewal, and shipped $\left(4^{\circ} \mathrm{C}\right)$ to ALS Environment (Kelso, WA, USA) for chemical analyses. After that and throughout the 10-day exposure, only stock solutions of oil prepared every 2 days with fresh oil and FSW control were sent for chemical analyses. Polycyclic aromatic hydrocarbons (PAHs), including alkyl homologues, were determined by gas chromatography with low resolution mass spectrometry using selected ion monitoring (GC/MS-SIM) and a sum of 50 different PAHs were quantified (Table 1). The sum concentrations of these $50 \mathrm{PAH}$ analytes are hereafter referred to as tPAH50. The analytical procedure was based on EPA Method 8270D with the GC and MS operating conditions optimized for separation and sensitivity of the targeted analytes (US EPA, 1986). Additional details regarding the methods used (e.g. standards used, QC criteria for surrogate recovery, internal standards, spiked blanks) can be found in the analytical QAPP provided by the analytical laboratory 
and applied to all samples analyzed for the Deepwater Horizon Natural Resource Damage

Assessment (DWH NRDA): https://pub-dwhdatadiver.orr.noaa.gov/dwh-ar-documents/945/DWH$\underline{\text { AR0101767.pdf }}$

\subsection{Statistical analyses}

241 All percentage data (mortality, tubule types) were arcsine-square root transformed to improve

\section{Results and Discussion}

\subsection{Water quality and analytical chemistry of oil solutions}

Temperature and salinity for all experiments were $25.4^{\circ} \mathrm{C} \pm 1.0$ and $25.4 \mathrm{PSU} \pm 0.8$, respectively. DO and $\mathrm{pH}$ averaged $6.3 \mathrm{mg} \mathrm{L}^{-1} \pm 0.4$ and $8.09 \pm 0.2$ respectively, and total ammonia concentration 
remained below deleterious levels $\left(\mathrm{NH} 3=0.0147 \mathrm{mg} \mathrm{L}^{-1} \pm 0.005\right)$. Two faulty aeration lines in 2

261 replicates within the control treatment of experiment 2 caused levels of DO to drop below $2 \mathrm{mg} \mathrm{L}^{-1}$ 262 on day 9, resulting in a mass mortality; as a result, only 3 replicates for the control condition were included. Seawater used for control treatments contained background concentrations of PAHs (tPAH50 $\left.=0.03 \mu \mathrm{g} \mathrm{L}^{-1} \pm 0.01\right)$ considered negligible for the present study. Nominal concentrations tested with corresponding sum concentration of 50 PAHs quantified by GC/MS-SIM are presented in Table 1, whereas PAH profile of the stock solutions of HEWAF throughout the 10-day exposure is shown in the Supplementary File.

Table 1: Range of nominal test dilutions in percentage of stock of HEWAF $\left(2 \mathrm{~g} \mathrm{~L}^{-1}\right)$, nominal concentrations in $\mathrm{mg}$ oil $\mathrm{L}^{-1}$, and corresponding measured tPAH50 (i.e. sum of 50 PAHs) concentrations, in $\mu \mathrm{g} \mathrm{L}^{-1}$, of the initial exposure solutions. Measured tPAH50 were only quantified in the stock solutions at renewal throughout the 10-day exposure, i.e. at Day 4, Day 6, and Day 8.

\begin{tabular}{|c|c|c|c|c|c|c|}
\hline & \% Stock & $\begin{array}{l}\text { Nominal } \\
\left(\mathrm{mg} \mathrm{oil} \mathrm{L}^{-1}\right)\end{array}$ & 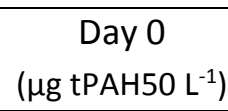 & $\begin{array}{c}\text { Day } 4 \\
(\mu \mathrm{g} \text { tPAH50 L-1 })\end{array}$ & 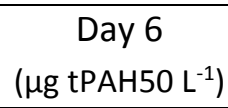 & $\begin{array}{c}\text { Day } 8 \\
\left(\mu \mathrm{g} \text { tPAH50 L }{ }^{-1}\right)\end{array}$ \\
\hline & 100 & 2000 & 3450 & 3588 & 3710 & 3383 \\
\hline & 25 & 500 & 904 & - & - & - \\
\hline HEWAF & 5 & 100 & 147 & - & - & - \\
\hline \multirow[t]{3}{*}{ Slick A } & 2.5 & 50 & 66 & - & - & - \\
\hline & 0.5 & 10 & 7 & - & - & - \\
\hline & 0 & 0 & 0.03 & - & - & - \\
\hline
\end{tabular}

HEWAF = high-energy water accommodated fraction; tPAH50 = sum concentration of 50 polycyclic aromatic hydrocarbons analytes quantified by GC-MS/SIM by ALS (Kelso, WA).

Bi- and tri-aromatic compounds were the major contributor to the PAH content of the stock solutions of HEWAF used throughout the spat exposure. Furthermore, alkylated PAHs such as C1-C4 277 naphtalene, fluorene or phenanthrene were more abundant than parent PAHs, a result in accordance 278 with our previous toxicity tests (Vignier et al., 2015; 2016) and other studies (Achten \& Andersson, 279 2015; Neff \& Anderson, 1981). These alkylated derivatives were shown to have increased toxicity to 280 invertebrates as a result of increased lipophilicity (Hawthorne et al., 2006). 
Oyster spat $(\approx 10-15 \mathrm{~mm}$ ) were exposed for 10 days to concentrations of HEWAF ranging from 7 to

$2833450 \mu \mathrm{g}$ tPAH50 $\mathrm{L}^{-1}$. Non-parametric statistical tests showed no significant differences in mortality 284 between control and exposed treatments (Kruskal-Wallis: $p=0.280$ ) (Fig. 2). Overall, only partial 285 mortalities were encompassed by the broad range of HEWAF concentrations tested, and no clear 286 dose-dependent mortality response in exposed oyster spat was observed. Highest mortalities were 287 observed at a relatively low concentration of oil $\left(66.7 \% \pm 16.8\right.$ at $\left.66 \mu \mathrm{g} \mathrm{tPAH} 50 \mathrm{~L}^{-1}\right)$ and at the 288 highest concentration $\left(57.8 \% \pm 15.5\right.$ at $3450 \mu \mathrm{g}$ tPAH50 L $\left.{ }^{-1}\right)$ compared to control $(22.2 \% \pm 8.9)$ (Fig. $2892)$

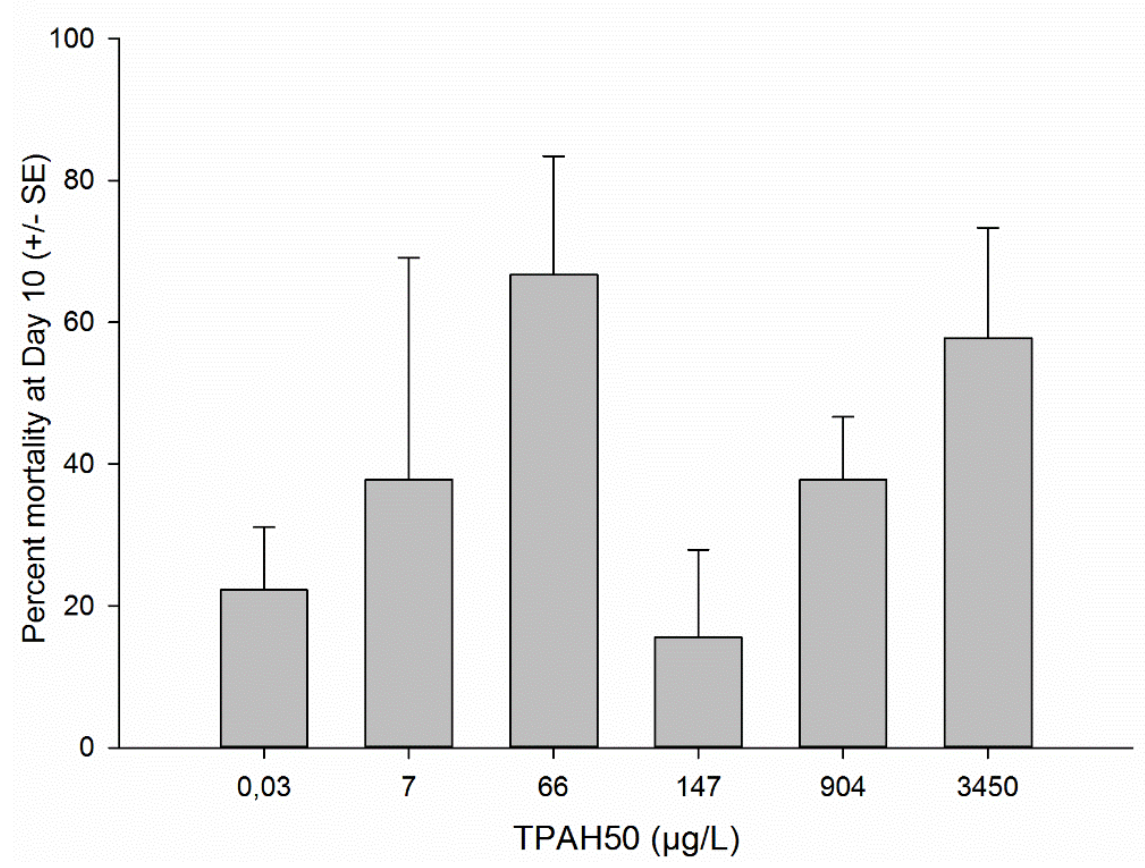

291 Figure 2: Mortality of spat following 10 days of exposure to increasing concentrations of HEWAF, 292 expressed in $\mu \mathrm{g}$ tPAH50 L $\mathrm{L}^{-1}$ (initial oil loading rate of $2 \mathrm{~g} \mathrm{~L}^{-1}$ ). Data are presented as mean 293 percentages $(n=3) \pm$ standard errors (SE). Seawater control treatment corresponds to $0.03 \mu \mathrm{g}$ tPAH50 $294 \mathrm{~L}^{-1}$. TPAH50 = sum concentration of 50 polycyclic aromatic hydrocarbons analytes quantified.

296 This is in accordance with our preliminary spat exposures (data not shown) and our previous study 297 exposing veliger stage of oyster larvae to HEWAF in which we found a non-dependent dose- 
298

response (Vignier et al., 2016). This lack of a clear dose-response relationship is noteworthy. A recent study by Forth et al. (2017) determined how different WAF preparation methods and concentrations influenced the chemical composition and concentration of PAHs in the dissolved and particulate phases over time. In HEWAF solutions prepared with the same starting oil-to-water ratio (i.e. $2 \mathrm{~g}$ oil $\mathrm{L}^{-1}$ ), the composition and concentration of the dissolved and particulate fractions varied

\subsection{Effects of HEWAF on clearance rates}


Clearance rates of spat fed Tisochrysis lutea were significantly impacted at all concentrations of HEWAF tested for $24 \mathrm{~h}\left(\mathrm{~F}_{4,10}=59.08, p<0.001\right.$; Fig. 3$)$. Each treatment reduced oyster feeding activity by at least 5 -fold compared to the control $\left(\mathrm{F}_{4,10}=59.08, p<0.05\right)$. In response to an environmental stress such as oil pollution, filter-feeding oysters can reduce their clearance rates by closing their valves, as a defense mechanism (Akberali \& Trueman, 1985). Concentrations of oil $\geq$ $100 \mathrm{mg} \mathrm{L}^{-1}$ (equivalent to $147 \mu \mathrm{g}$ tPAH50 $\mathrm{L}^{-1}$ ) caused a significant reduction in the clearance rate of oyster spat regardless of the concentration tested (Fig. 3).

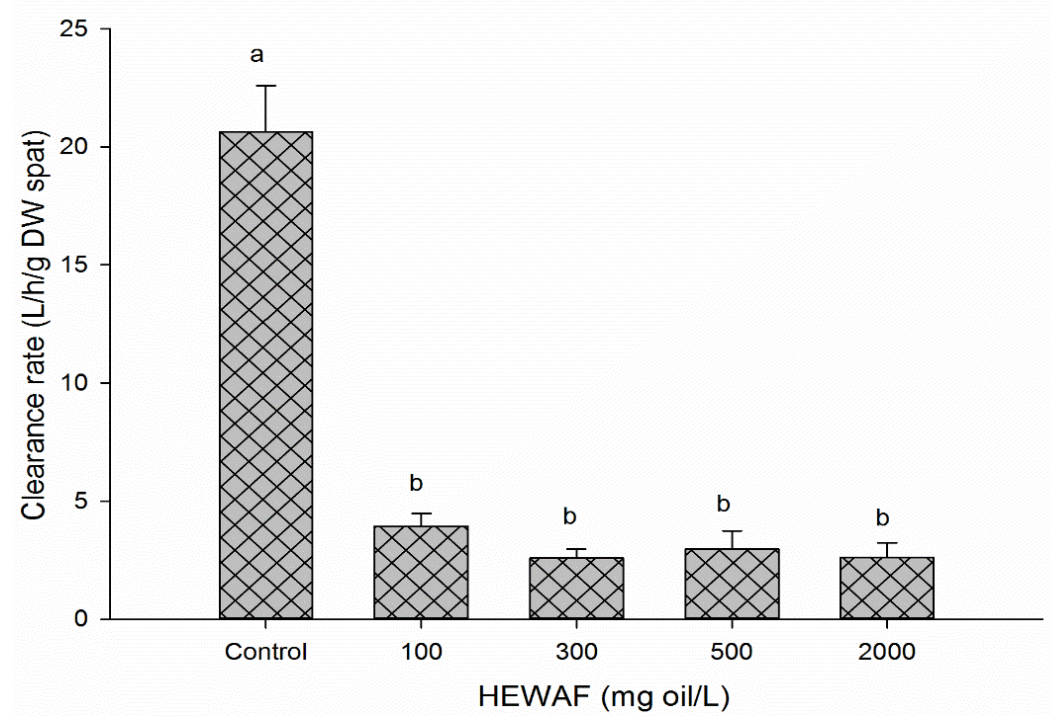

Figure 3: Clearance rates of Tisochrysis lutea by oyster spat exposed for $24 \mathrm{~h}$ to nominal concentrations of HEWAF (in mg oil $\mathrm{L}^{-1}$ ), expressed in $\mathrm{L}^{-1} \mathrm{~h}^{-1} \mathrm{~g}^{-1} \mathrm{DW}$ of oyster tissue. Data are presented as mean percentages $(n=3) \pm$ standard errors (SE). Different letters denote statistical differences compared to control (ANOVA; $p=0.05)$. HEWAF $=$ high-energy water accommodated fraction; DW = Dry weight.

This inhibition of clearance rates, similar across all treatments, suggests valve closure as a potential avoidance response. Other studies have also reported a decline in filtration rates of bivalves in response to hydrocarbons (Barszcz et al., 1977; Galtsoff et al., 1935; Widdows et al., 1982). Several reasons could explain this reduced feeding activity, the most obvious being a mechanical action of oil droplets by coating of the gills, thus disabling the normal efficiency of the ctenidia to sort and absorb food particles (Galtsoff et al., 1935). Exposure of the gill tissue of hard clams to toxic algae exerted 
343

an irritation, causing a cessation of ciliary activity (Gainey \& Shumway, 1991). In the same way, oil/PAHs could have induced a cessation of the ciliary motion, inhibiting feeding rates. In the current study, instances of erosion of gill filaments were observed in some individuals, indicative of an apparent irritation and toxicity by contact. Our results (i.e. high concentrations of 2 and 3 ring alkylated PAHs; see supplementary file) could also be explained by another study which suggested 348 that bi- and tri-aromatic hydrocarbons could induce a narcotizing effect on the ciliary feeding 349 mechanisms of Mytilus edulis, reducing clearance rates (Donkin and Widdows, 1990).

\subsection{Effects of HEWAF on digestive morphometry}

Measurements of the digestive tubule (DGT) lumen ratio in tissue sections of both control and experimental oysters indicated that exposure to increasing concentrations of slick oil prepared as HEWAF induced a significant increase of the luminal tubule ratio compared to control $\left(\mathrm{F}_{5,30}=7.817\right.$, $p<0.001$; Fig. 4A). The number of DGT with dilated lumens (Type III, Fig. 1) increased in a dose-

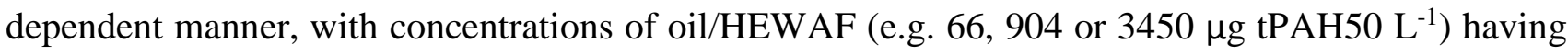
a significant effect $\left(\mathrm{F}_{5,30}=7.817, p \leq 0.01\right.$; Fig. 4A $)$.
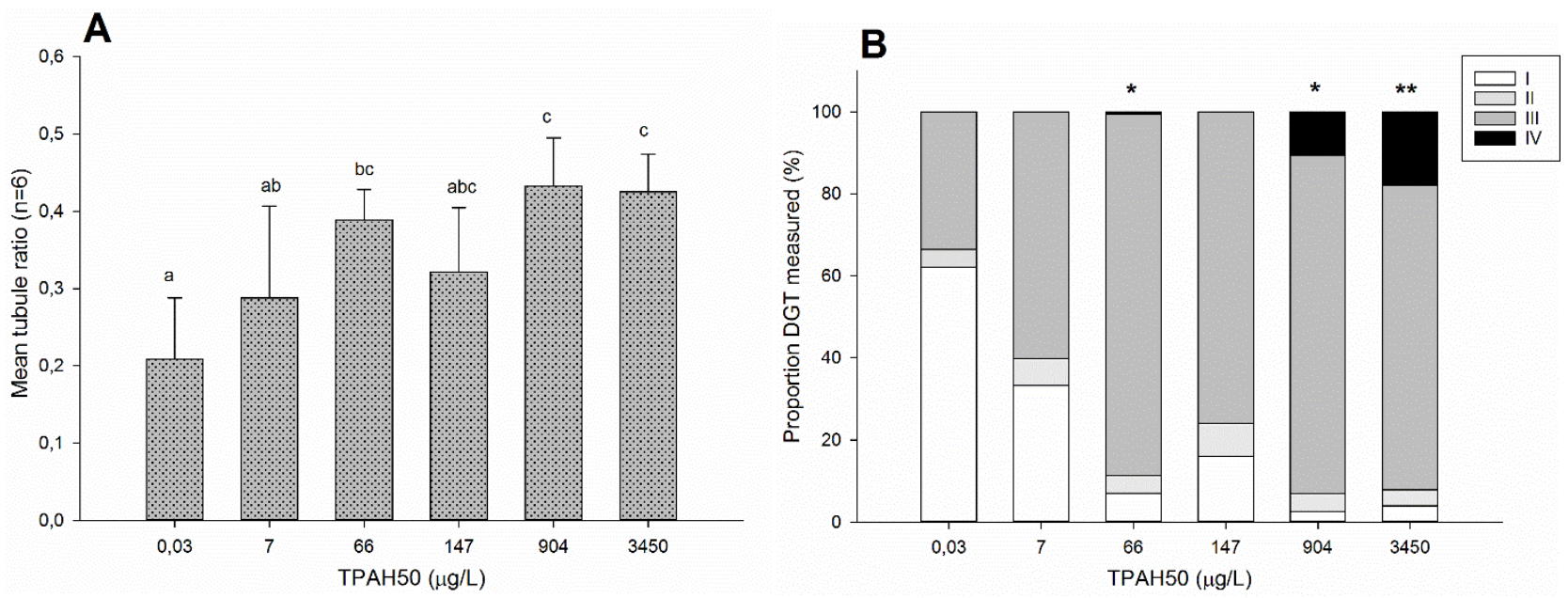

Figure 4: (A) Mean tubule luminal ratio $( \pm \mathrm{SD})$ from 6 oysters exposed for 10 days to increasing concentrations of HEWAF, expressed in $\mu \mathrm{g}$ tPAH50 $\mathrm{L}^{-1}$. Different letters denote a statistical difference (ANOVA: $p=0.05$ ). (B) Proportion (in percent) of the different digestive tubule (DGT) types observed in histological sections of spat $(n=6)$, exposed for 10 days to HEWAF ( $\mu$ g tPAH50 L-1). Scoring method 
362

(2.3.3.2c) as follow: stage I: absorption; stage II: disintegration; stage III: reconstitution; stage IV: necrotic. Asterisks denote a statistical difference compared to control (ANOVA: $p=0.05$ ).

364 Furthermore, compared to control oysters, 10 days of exposure to oil induced significant changes in 365 phasic activity between the different stages of tubules observed among treatments $\left(\mathrm{F}_{5,30}=11.221\right.$, $366 p<0.001$; Fig. 4B). Concentrations of HEWAF, i.e. 66,904 , and $3450 \mu \mathrm{g}$ tPAH50 L ${ }^{-1}$, significantly 367 impacted the proportion of tubule types $\left(F_{5}, 30=11.221, p \leq 0.05\right.$; Fig. $\left.4 \mathrm{~B}\right)$ in a dose-dependant 368 manner with a significant shift observed from stage I to III (Fig. 4B). Overall, histological sections of 369 oil-exposed oysters showed that digestive diverticula were typical in appearance to that seen during

\subsection{Effects of HEWAF on tissue condition}

A variety of pathological conditions were observed after 10 days of exposure to mechanically dispersed oil (HEWAF). Our observations focused on connective tissue (Fig. 5A), gills, labial palp (Fig. 5C), and mantle which were in direct contact with the oil solutions. In addition, organs of the digestive system, such as stomach (Fig. 6), intestine, digestive ducts and tubules (Fig. 7) were 
388 402

specifically studied. Conditions such as; erosion of gill filaments, hemocyte infiltration in the water

389 tubules of the gills or in the labial palp, high instances of mucus secretory cells in the digestive tubules and digestive ducts epithelia (i.e. mucus diapedesis), or parasitic infestation (Tylocephalum) were commonly observed in the oysters after 10 days, but distributed in all experimental treatments, exposed or not to oil. The histopathological condition of non-exposed spat at the start of the exposure (i.e. control Day 0; Table 2) suggests that a severe change in salinity from the original to the experimental condition during acclimation, as well as a potential poor health condition of the spat to begin with may have caused the observed high mortality in the non-exposed, control oysters after 10 days.

397 Nonetheless, oil-exposed spat differed from the control group in a number of aspects. In the stomach 398 for instance, little food or digested material was found, particularly in those exposed to $66 \mu \mathrm{g}$ 399 tPAH50 L-1 and higher. This finding is in line with our observations of oyster spat upon exposure, 400 i.e. filtration reduction and occurrence of atrophy in the digestive diverticula.

401 One of the main histological features observed in exposed animals was the significant presence of syncytia in the connective tissue, in very high numbers compared to control (Fig. 5A \& B) (U-test: $p<0.05$, Table 2). In the gills, the presence of syncytia was consistently observed in all oil treatments except the $66 \mu \mathrm{g}$ tPAH50 L $\mathrm{L}^{-1}$ dose, reaching up to $38.5 \%$ of the oysters at $7 \mu \mathrm{g}$ tPAH50 L $\mathrm{L}^{-1}$ as compared to $5.3 \%$ in control (Table 2). Syncytia are defined as a multinucleate mass of protoplasm produced by the fusion of several cells (Dorland, 2011). Syncitia can be normal cells in animal biology (e.g. some type of fungi), but hemocytes are mononuclear cells and their merging together to form syncytia is a serious pathology, indicative of a severe inflammatory response. For instance, syncytia can form when cells are infected by certain types of viruses such as HIV, causing changes in immunology and surface antigens of the cells and ultimately apoptosis (Huerta et al., 2009). Formation of polykaryons cells (giant cells, syncytia) has been recorded in vertebrates in response to inflammation (Lewis \& Lewis, 1926; Mariano \& Spector, 1974) but more rarely reported in invertebrates (Anderson, 1987). The presence of syncytia may impair the immune response of 
affected organisms, and the relationship between syncytia formation and oil-exposure requires

415 further research.

416 In the labial palp epithelium, hemocytic diapedesis was observed more often in oil-exposed spat (Fig.

417 5D) than in non-exposed spat (Fig. 5C), particularly at the highest doses (100\% of the oysters) (U418 test: $p \leq 0.05$, Table 2). Combined with hemocyte infiltration in the water tubules, these features 419 indicate a direct contact between soluble PAHs and/or oil droplets with the labial palp via filtration.

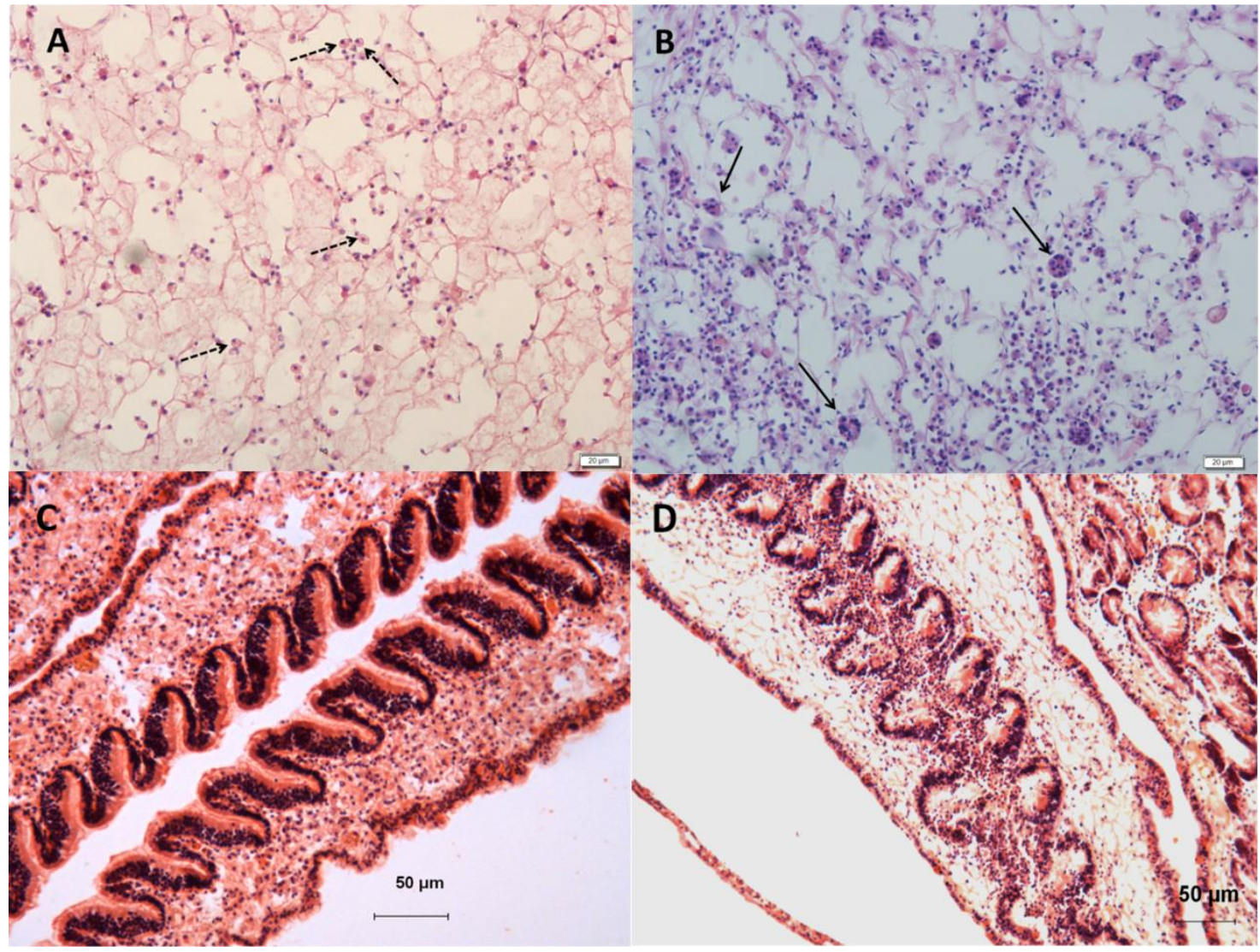

421 Figure 5: (A) healthy connective tissue with normal hemocytes and presence of phagocytosing 422 hemocytes (dashed arrows), observed in non-exposed group after 10 days; (B) connective tissue

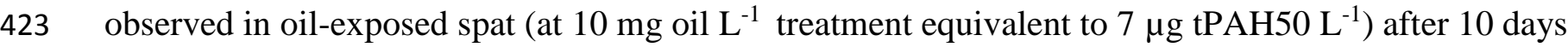
424 showed high instance of syncytia (arrows); (C) Normal labial palp observed after 10 days in control 425 oyster; (D) abnormal labial palp exhibiting major hemocyte infiltration $\left(100 \mathrm{mg} \mathrm{L}^{-1}\right.$ treatment 426 equivalent to $147 \mu \mathrm{g}$ tPAH50 $\mathrm{L}^{-1}$ ).

427 Acute exposure to oil prepared as HEWAF negatively affected the digestive system of oyster spat. In 428 addition to DGT atrophy mentioned previously, histological examination of the digestive diverticula 
429

and the gastro-intestinal tract revealed a major inflammatory response upon oil-exposure. After 10 430 days, the occurrence of severe pathological conditions such as ulcers (Fig. 6B) and epithelial 431 sloughing (Fig. 6D) were found in a greater number of oysters at 66 and $147 \mu \mathrm{g}$ tPAH50 L-1 432 exposure concentrations compared to controls (U-test, $p \leq 0.1$, Table 2). Hemocyte proliferation in the 433 connective tissue surrounding the digestive diverticula, as well as severe hemocyte diapedesis (Fig. 434 6C) and infiltration into the lumen of the alimentary tract (Fig. 6D) occurred significantly more in 435 oil-exposed oysters than in non-exposed oysters (U-test, $p \leq 0.1$, Table 2).

436 A recent study from Luna-Acosta (2017) also found that the digestive gland of oysters exposed to 437 mechanically dispersed oil showed hemocyte infiltrations. Significant migration of hemocytes by 438 diapedesis from the vascular system into the stomach and the intestine is part of a defense 439 mechanism in bivalves (Feng, 1966; Galimany et al., 2008). In the presence of oil, oyster hemocytes 440 can migrate to engulf and encapsulate foreign material (Sami et al., 1992). Enzyme activities can be 441 activated in hemocytes of $C$. gigas exposed to crude oil, and may play an important role in protection 442 against xenobiotics (Luna-Acosta et al., 2011). Thus, as an attempt to eliminate oil, hemocytes may 443 migrate from the connective tissue through the epithelia of the stomach/intestine by diapedesis, 444 carrying the compounds to the alimentary canal (intestine) for elimination by excretion in the feces. 445 This process was confirmed in our study by observation of actively phagocytosing hemocytes in the 446 connective tissue (Fig. 5A \& 6C) and apoptotic hemocytes in the lumen of the stomach/intestine 447 (Fig. 6D). Such a detoxification pathway has been described in mussels challenged with 448 environmental stressors or toxic algae; this process was associated with an increase of tissue lipid 449 peroxidation due to an oxidative stress (Alves de Almeida et al., 2007; Galimany et al., 2008). 


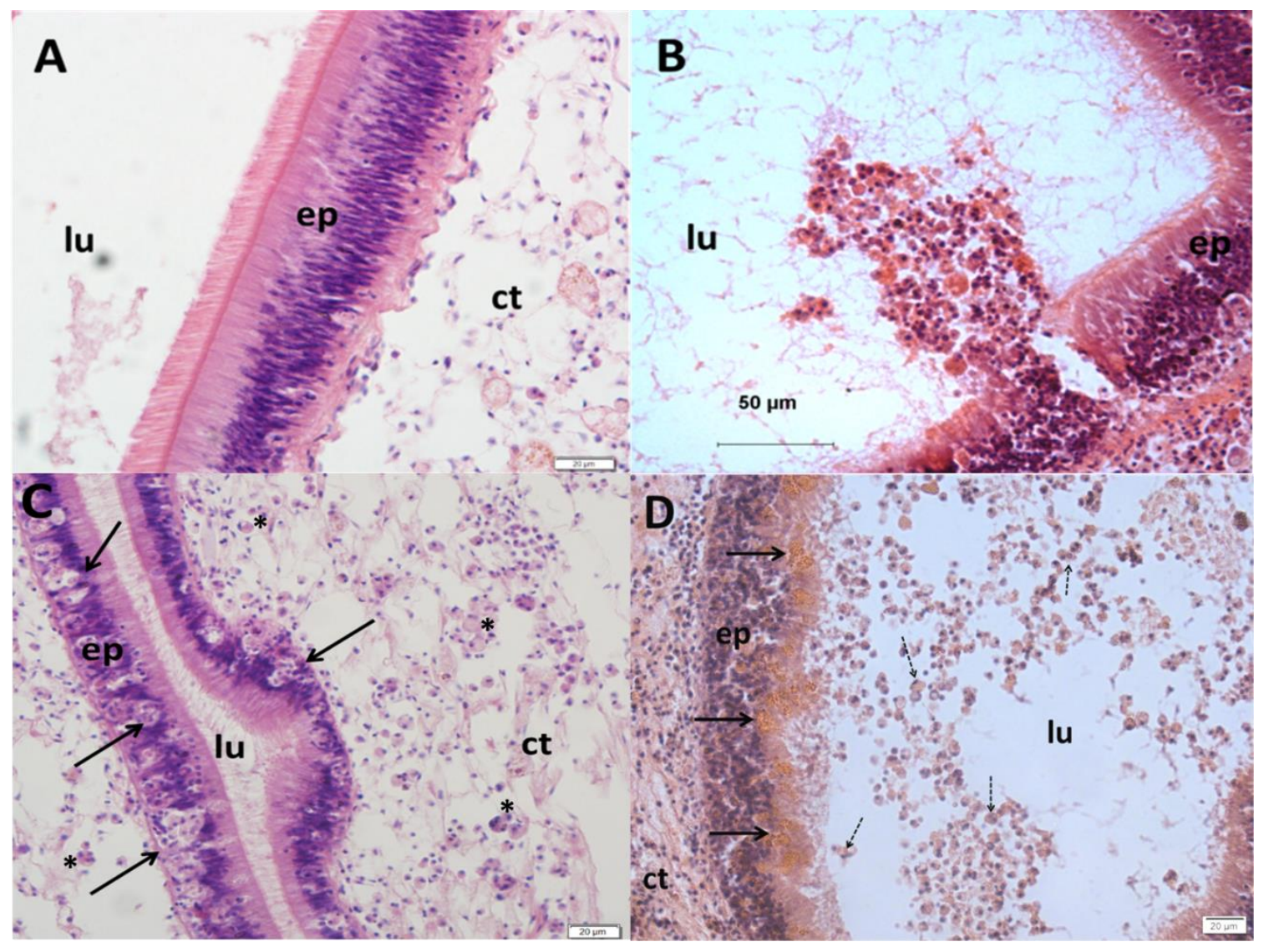

451 Figure 6: Section of the stomach of experimental oyster after 10 days of exposure to HEWAF. (A) Normal 452 epithelium in non-exposed oyster; (B) example of ulcer and consequent hemorrhaging of hemolymph in the

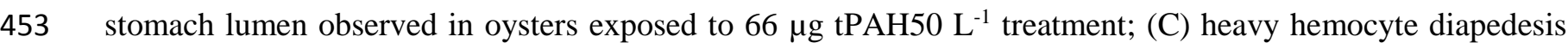
454 (arrows) from the connective tissue into the lumen of the stomach $\left(7 \mu \mathrm{g}\right.$ tPAH50 L $\left.{ }^{-1}\right)$. Asterisks note the 455 presence of phagocytosing hemocytes as well as syncytia; (D) severe hemocyte infiltration coupled with

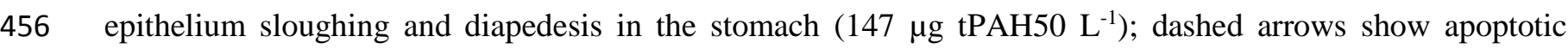
457 hemocytes; arrows show oil accumulated in epithelia. $c t=$ connective tissue; lu = lumen; ep = epithelium.

460 An excess of mucus in the alimentary canal and a high prevalence of hypertrophic mucus secretory 461 cells in the epithelia (referred as mucus diapedesis) of the stomach/intestine were also consistently 462 observed in exposed spat (U-test: $p \leq 0.05$, Table 2, Fig. 6D). Although mucus secretory cells are a 463 normal cell type in epithelia of the digestive gland, their increased number and abnormal size in oil464 exposed oyster may indicate hyperplasia, which could be a severe pathology directly imputable to 465 contact with oil droplets/dissolved PAHs (Domingos et al., 2007). 
467 Table 2: Histological parameters recorded in Crassostrea virginica tissues at day 0 and after 10 days

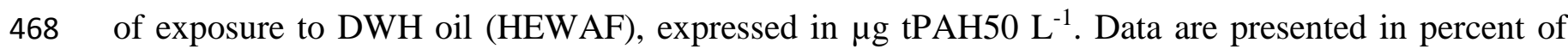
469 occurrence per treatment. Mann-Whitney/U-test compares treatments with control Day10: statistical 470 difference at $p=0.1$.

\begin{tabular}{|c|c|c|c|c|c|c|c|}
\hline \multirow{2}{*}{$\begin{array}{l}\text { Histological } \\
\text { features }\end{array}$} & \multicolumn{5}{|c|}{ Measured HEWAF ( $\mu \mathrm{g}$ tPAH50 L-1) } & \multirow[b]{2}{*}{908} & \multirow[b]{2}{*}{3450} \\
\hline & $\begin{array}{c}\text { Control } \\
\text { Day } 0\end{array}$ & $\begin{array}{l}\text { Control } \\
\text { Day } 10\end{array}$ & 7 & 66 & 147 & & \\
\hline \multicolumn{8}{|l|}{ GILLS } \\
\hline Syncytia & 0 & 5.3 & $38.5^{* *}$ & 0 & 15.8 & 18.2 & 9.1 \\
\hline $\begin{array}{l}\text { Hemocyte } \\
\text { infiltration }\end{array}$ & 0 & 0 & $15.4^{\#}$ & 12.5 & 5.3 & 9.1 & 9.1 \\
\hline $\begin{array}{l}\text { Erosion of } \\
\text { filament }\end{array}$ & 8.6 & 0 & 0 & 12.5 & 0 & 0 & 9.1 \\
\hline \multicolumn{8}{|l|}{ PALP } \\
\hline Diapedesis & $5.2^{*}$ & 46.2 & 75 & 66.7 & 57.1 & $100^{*}$ & $100^{*}$ \\
\hline $\begin{array}{l}\text { Hemocyte } \\
\text { infiltration }\end{array}$ & 0 & 7.7 & $50^{*}$ & 33.3 & 14.3 & $57.1^{*}$ & 28.6 \\
\hline \multicolumn{8}{|c|}{ CONNECTIVE TISSUE } \\
\hline Syncytia & 11.5 & 31.8 & $92.3^{* * *}$ & $75^{*}$ & $84.2^{* * *}$ & $92.3^{* * *}$ & $84.6^{* *}$ \\
\hline \multicolumn{8}{|c|}{ STOMACH/INTESTINE } \\
\hline $\begin{array}{l}\text { Epithelium } \\
\text { sloughing }\end{array}$ & 0 & 5.3 & 11.1 & $33.3^{\#}$ & $26.7^{\#}$ & 15.4 & 0 \\
\hline Ulcer & 0 & 0 & 0 & $33.3^{* *}$ & $20^{*}$ & 7.7 & 0 \\
\hline $\begin{array}{l}\text { Hemocyte } \\
\text { diapedesis }\end{array}$ & $40^{*}$ & 79 & 100 & 100 & $100^{\#}$ & $100^{\#}$ & 84.6 \\
\hline $\begin{array}{l}\text { Hyperplasia } \\
\text { mucus cells }\end{array}$ & 25 & 21.1 & $78^{* *}$ & $66.7^{*}$ & $60^{* *}$ & $76.9^{* *}$ & $69.2^{* *}$ \\
\hline $\begin{array}{l}\text { Hemocyte } \\
\text { infiltration }\end{array}$ & $15^{*}$ & 57.9 & $100^{*}$ & 83.3 & $93.3^{\#}$ & $92.3^{*}$ & 76.9 \\
\hline $\begin{array}{l}\text { Mucus } \\
\text { infiltration }\end{array}$ & 10 & 31.6 & $88.9^{* *}$ & 50 & 46.7 & 53.9 & $61.5^{\#}$ \\
\hline \multicolumn{8}{|c|}{ DIGESTIVE DIVERTICULA } \\
\hline $\begin{array}{l}\text { Epithelium } \\
\text { sloughing }\end{array}$ & 0 & 31.8 & $100^{* * *}$ & 37.5 & $89.5^{* * *}$ & $76.9^{* *}$ & $66.7^{*}$ \\
\hline $\begin{array}{l}\text { Digestive cells } \\
\text { in lumen }\end{array}$ & $7.7^{*}$ & 36.4 & $100^{* * *}$ & 50 & $94.7^{* * *}$ & $84.6^{* *}$ & $66.7^{\#}$ \\
\hline $\begin{array}{l}\text { Hemocyte } \\
\text { diapedesis }\end{array}$ & 0 & 13.6 & $53.9^{* *}$ & $50^{*}$ & $47.4^{*}$ & $61.5^{* *}$ & 8.3 \\
\hline $\begin{array}{l}\text { Hyperplasia } \\
\text { mucus cells }\end{array}$ & 7.7 & 9.1 & 30.8 & 12.5 & 15.8 & $30.8^{\#}$ & $33.3^{\#}$ \\
\hline $\begin{array}{l}\text { Oil in } \\
\text { lumen }\end{array}$ & 0 & 0 & 0 & 0 & 5.3 & 7.7 & 8.3 \\
\hline
\end{tabular}


471 Data were categorized as 0 or 1 , according to the absence (0) or presence (1) of the observed feature; Mann-

472 Whitney/U-tests were performed: ${ }^{\#} \mathrm{p} \leq 0.1 ; * \mathrm{p} \leq 0.05 ; * * \mathrm{p} \leq 0.01 ; * * * \mathrm{p} \leq 0.001$, ${ }^{\text {T Three oysters had this }}$

Compared to non-exposed oysters (Fig. 7A), the digestive diverticula of oil-exposed oysters showed a predominance of dilated lumina of the DGT (Fig. 7B). In addition, migration of hemocytes by diapedesis into the lumen of the digestive ducts (DD), epithelium sloughing and presence of digestive cells in the lumina of the DD and DGT, were observed in most of the exposure groups (Utest, $p<0.05$, Table 2) (Fig. 7C). More specifically, a prevalence (10 to 18\%) of necrotic tubules was noted at the highest HEWAF concentrations tested (904 and $3450 \mu \mathrm{g}$ tPAH50 L ${ }^{-1}$ ), with cellular debris and digestive cells, most often in apoptosis, sloughed into the lumen of tubules and ducts (Fig. 7C). It is evident from these observations that a degeneration of the digestive cells lining the DGT epithelia and subsequent sloughing into the lumen was related to exposure to hydrocarbons. Likewise, epithelium sloughing was described in oysters collected from the field following the Amoco Cadiz spill (Neff \& Haensly, 1982) and with chronic experimental exposures (Barszcz et al., 1977).

Instead of partially digested food material ready to be taken in by digestive cells for intracellular digestion, abnormal excretion product (i.e. mucus) and possibly oil were observed in the lumen of the DD and DGT from three spat exposed to the highest doses of HEWAF (Fig. 7D, Table 2). In light of these observations, it is possible that oysters directly ingested oil as droplets, carried it to the stomach via the labial palps, and transferred it to the lumen of DGT by the ciliated epithelia of the DD. As part of the DWH natural resource damage assessment, Forth et al. (2017) characterized the oil droplets size distribution in HEWAF dilutions used in our toxicity testing. Their results revealed that the initial mean diameters of the HEWAF droplets were $8 \mu \mathrm{m}$ and decreased to $5 \mu \mathrm{m}$ after $48 \mathrm{~h}$, a size range of particle well within the food spectrum available to filter-feeding oyster. 


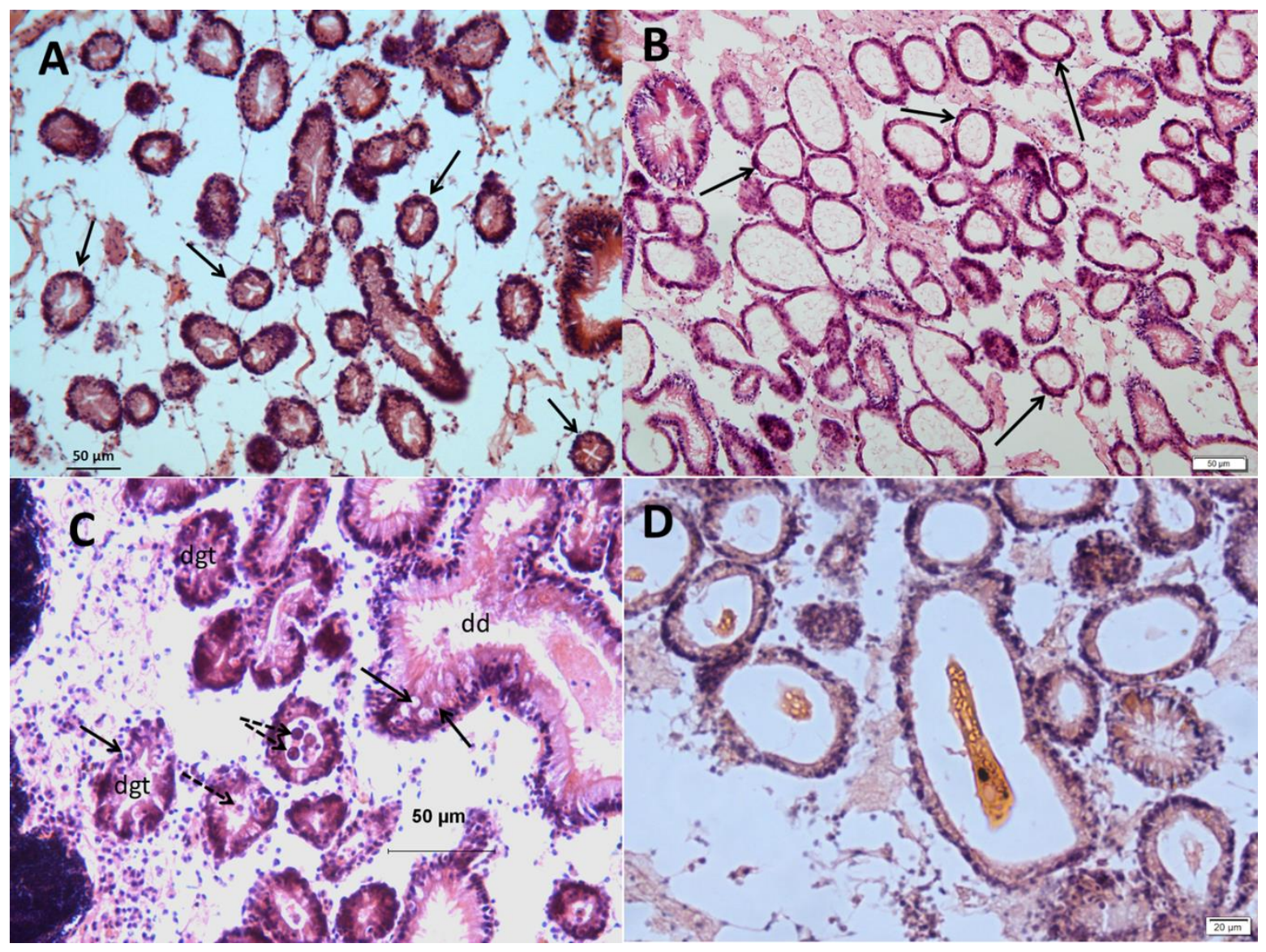

497 Figure 7: Histological preparations of Crassostrea virginica cross-sections (A) show predominantly normal 498 (Type I) tubules (arrows); (B) arrows show severe metaplastic changes (Type III), with dilation of the lumina 499 and loss of epithelial cell height; (C) section of digestive diverticulum (100 mg oil $\mathrm{L}^{-1}$ treatment equivalent to $500147 \mu \mathrm{g}$ tPAH50 L ${ }^{-1}$ ) showing necrotic stage of DGT (Type IV) with sloughing of digestive cells (dashed 501 arrow) in the lumen of digestive tubules as well as hemocyte diapedesis (arrows) in epithelia of tubules and 502 digestive ducts; (D) example of tubules and ducts with presence of oil in lumen observed in the $2000 \mathrm{mg} \mathrm{L}^{-1}$ 503 treatment (corresponding to $3450 \mu \mathrm{g}$ tPAH50 L ${ }^{-1}$ ). dgt = digestive tubules; dd = digestive ducts.

505 Figure 8A summarizes the mean number of pathological conditions observed per individual for each concentration of HEWAF tested. For most concentrations of HEWAF tested, an increase in the 507 number of pathologies was observed in every organ studied in comparison to control oysters. Acute 508 exposure to oil also affected the digestive system, where most histopathological conditions were 509 reported, particularly in the gastro-intestinal system (Fig. 8A). A focus on the stomach and intestine 510 revealed a significant increase in the intensity of pathologies compared to control (Fig. 8B). 511 Surprisingly, concentration of $7 \mu \mathrm{g}$ tPAH50 L ${ }^{-1}$ seemed to induce more intense pathologies compared 


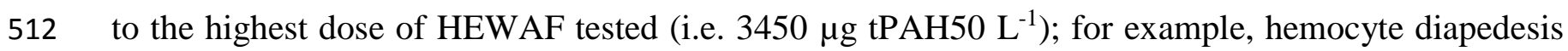

513 and hemocyte infiltration were significantly more intense at $7 \mu \mathrm{g}$ tPAH50 $\mathrm{L}^{-1}$ than at $3450 \mu \mathrm{g}$ 514 tPAH50 L $\mathrm{L}^{-1}$ (U-test, $p \leq 0.05$, Fig. 8B). Altogether, the gastro-intestinal system appeared to be the 515 most impacted tissues with a significant increase of pathology intensity as compared to control.

516 It may be that the chemical characteristics of low concentrations of HEWAF and particularly the 517 proportion of dissolved to particulate (i.e. droplets associated) PAHs - which increases with 518 decreasing total concentration through time (Forth et al., 2017) - could have contributed to these 519 augmented sub-lethal effects. Filtration results, which indicated no difference of clearance between 520 oil treatments, and the variable mortalities observed could support this hypothesis. Further research 521 should be conducted on the respective cause of toxicity from dissolved and particulate oil/droplets.

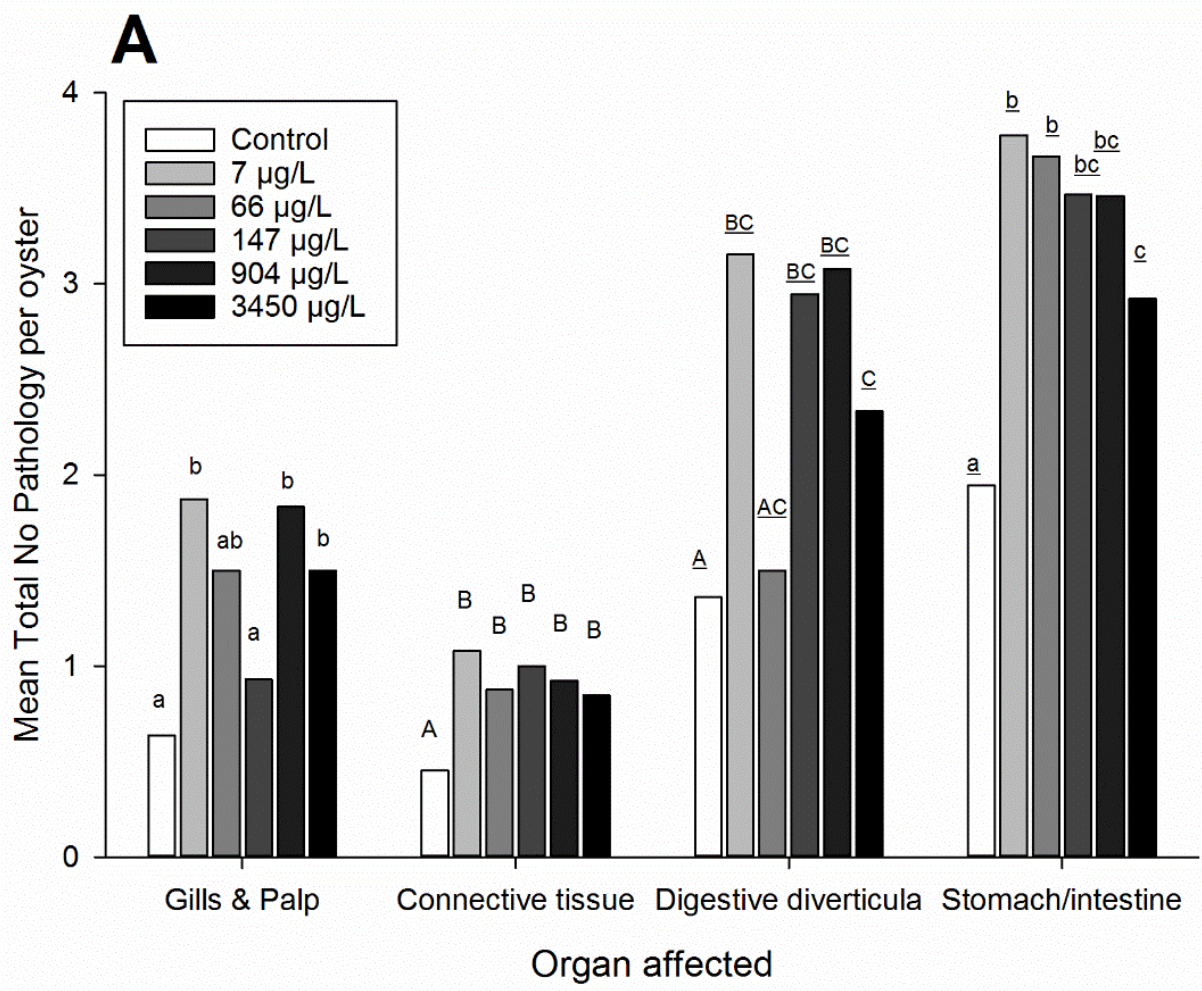




\section{B}

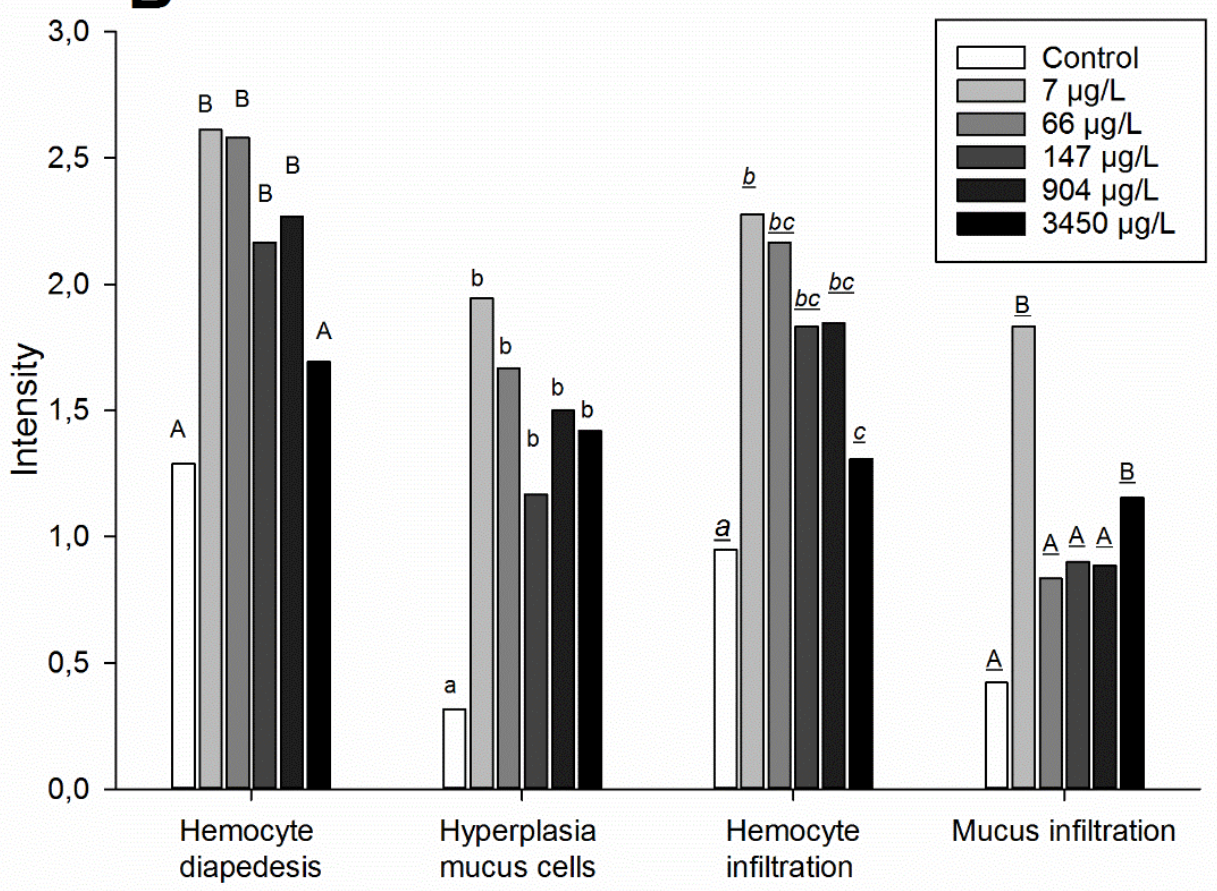

Pathological conditions

Figure 8: (A) Organ distribution of total pathological conditions observed per oyster $(\mathrm{n} \geq 9)$ following 10 days of exposure to increasing concentrations of HEWAF, expressed in $\mu \mathrm{g}$ tPAH50 L $\mathrm{L}^{-1}$. (B) Occurrence of various pathological conditions observed in the gastro-intestinal system (stomach/intestine) of oyster spat ( $\mathrm{n} \geq$ 9) after 10 days of exposure to HEWAF, expressed in $\mu \mathrm{g}$ tPAH50 $\mathrm{L}^{-1}$. Occurrence of pathological conditions are categorized by intensity following a semi-quantitative scale (see details in 2.3.3.2.a); 0: absence, 1: light, 2: moderate, 3: severe. Different letters within each organ/pathological condition denote statistical difference at $\mathrm{p} \leq 0.1$ (Mann-Whitney/U-test). Lettering differed between categories because separate analyses were performed for each organ/condition.

\subsection{Effects of HEWAF on lipid peroxidation}

For oysters exposed to increasing HEWAF concentrations, a trend of increased malondialdehyde (MDA, i.e. a marker for oxidative stress) level from 0 to $147 \mu \mathrm{g}$ tPAH50 L ${ }^{-1}$ and a trend of decreased MDA level from $147 \mu \mathrm{g}$ tPAH50 $\mathrm{L}^{-1}$ to $3450 \mu \mathrm{g}$ tPAH50 $\mathrm{L}^{-1}$ (Fig. 9) were observed in the tissue. Furthermore, concentrations of the lipid peroxidation byproduct were relatively high in the tissue sampled from the $147 \mu \mathrm{g}$ tPAH50 $\mathrm{L}^{-1}$ group $\left(13.6 \mu \mathrm{mol} \mathrm{g}{ }^{-1}\right)$. However, none of these results show any statistical significance $\left(\mathrm{F}_{5,15}=0.946, p=0.480\right)$ due to the high individual variability. Chronic, 
540 long-term exposure of bivalves to crude oil can induce an oxidative stress and impair membrane

541 integrity, associated with lipid peroxidation (Di Giulio et al., 1989; Downs et al., 2002; Livingstone 542 et al., 1989; 2001). Perhaps the duration of exposure tested in our study was too short to result in a 543 significant oxidative stress measurable using the MDA biomarker.

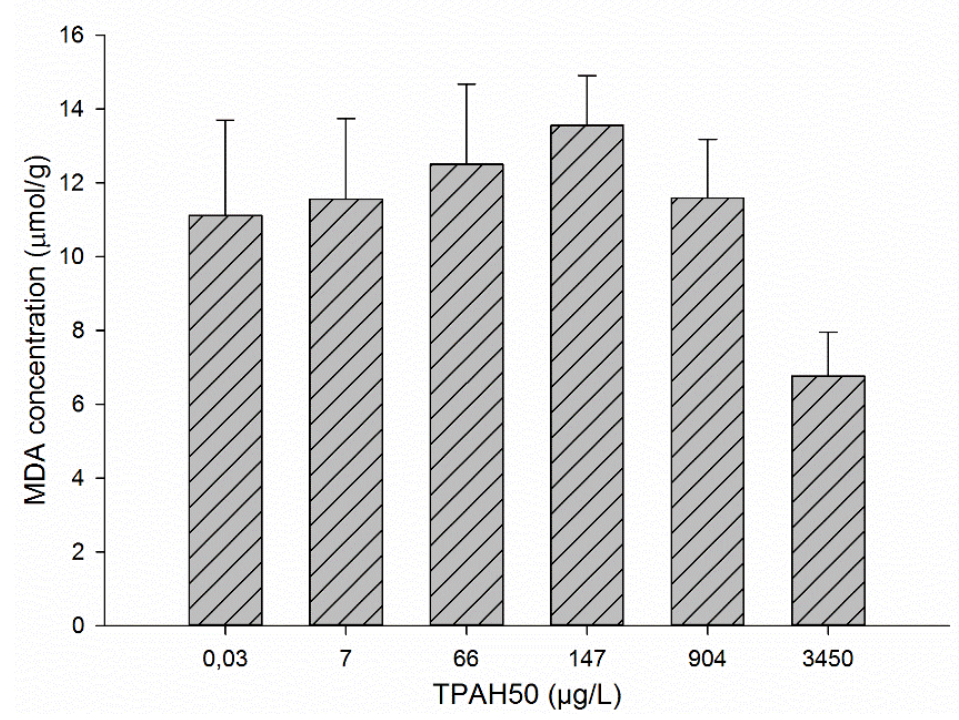

545 Figure 9: Mean malondialdehyde (MDA) concentration $( \pm \mathrm{SE})$, expressed in $\mu \mathrm{mol} \mathrm{g}^{-1}$ of oyster tissue, in spat 546 exposed for 10 days to increasing doses of oil prepared as HEWAF, expressed in $\mu \mathrm{g}$ tPAH50 L-1.

\section{4. Conclusions}

548 This study revealed lethal and sublethal effects of DWH oil on an ecologically important organism of 549 the Gulf of Mexico, the oyster Crassostrea virginica. Relatively high concentrations of DWH oil

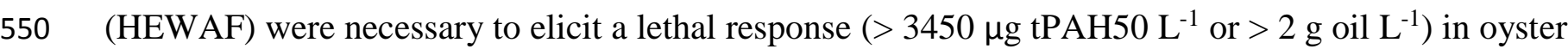
551 spat. If we consider the mortality data in conjunction with the histopathological changes observed on

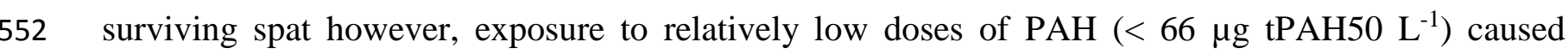
553 severe alterations in the physiology and metabolism of these animals. The present study also 554 demonstrated that an inflammatory response occurred, with various degrees of severity depending of 555 HEWAF doses, mostly located around the alimentary canal and the connective tissue. Stress associated with shipping, acclimation and holding oysters in static-renewal conditions during 
557

exposure could have contributed to the apparent poor condition of oysters in the control (both day 0 and day 10) and the unexpectedly elevated mortality in the control at the end of the exposure (> 20\%). However, the differences between controls and experimental treatments showed significant difference suggesting that oil had an impact.

Oysters are the principal benthic filter-feeders in the northern region of the Gulf of Mexico and appear to be, from the present study, sensitive to crude oil. Although these laboratory results showed significant sub-lethal effects in oysters exposed to DWH oil, these results cannot be extrapolated directly to the environment or to the natural oyster population. The lowest effective dose of PAHs determined in the current study (i.e., $7 \mu \mathrm{g}$ tPAH50 $\mathrm{L}^{-1}$ for tissue damage) was greater than most tPAH50 concentrations measured in coastal-water samples during and after the DWH spill (e.g., 0.17 $\mu \mathrm{g}$ tPAH33 L ${ }^{-1}$; Allan et al., 2012). It must be noted however that in the natural environment, oil can potentially interact with other abiotic factors (e.g. temperature, salinity, UV irradiance, xenobiotics) which may exacerbate the toxicity of its compounds to oysters (Pelletier et al., 1997; Powers et al., 2015). Further research is warranted to elucidate the effects of multiple stressors in combination with petroleum hydrocarbons on the physiology of oyster spat. Finally, information collected in the present study can be used in the selection of meaningful endpoints in addition to lethality for assessing oil spill effects.

\section{Acknowledgements}

576 This work was supported by funds provided as part of the natural resource damage assessment 577 (NRDA) for the Deepwater Horizon oil spill. The findings and conclusions presented in this study 578 are those of the authors and do not necessarily represent the view of National Oceanic and 579 Atmospheric Administration (NOAA) or of any other Trustees for the BP/Deepwater Horizon 580 NRDA. We would like to thank Abt Associates, particularly Michelle Krasnec and Jeffrey Morris for 581 their contributions. We thank Scott Rikard at the Auburn University Shellfish Laboratory, Dauphin 
of Agriculture for her unlimited knowledge on shellfish histopathology, and to Hélène Hégaret for a review of an earlier version of the manuscript. Finally, this study would not have been possible without the technical assistance from graduate students and staff at the Vester Field Station, especially Gaelle Richard, Molly Rybovich, Nicole Martin, Emily Standen-Nickols, and Audrey Barbe.

\section{References}

Achten, C., \& Andersson, J. T. (2015). Overview of polycyclic aromatic compounds (PAC). Polycyclic aromatic compounds, 35(2-4), 177-186.

Akberali, H. B., \& Trueman, E. R. (1985). Effects of environmental stress on marine bivalve molluscs. Adv. Mar. Biol, 22, 101-198.

Allan, S.E., Smith, B.W., \& Anderson, K.A. (2012). Impact of the Deepwater Horizon oil spill on bioavailable polycyclic aromatic hydrocarbons in Gulf of Mexico coastal waters. Environmental Science \& Technology 46, 2033-2039.

Alves de Almeida, E., Celso Dias Bainy, A., Paula de Melo Loureiro, A., Regina Martinez, G., Miyamoto, S., Onuki, J., \& Di Mascio, P. (2007). Oxidative stress in Perna perna and other bivalves as indicators of environmental stress in the Brazilian marine environment: Antioxidants, lipid peroxidation and DNA damage. Comparative Biochemistry and Physiology Part A: Molecular \& Integrative Physiology, 146(4), 588600 .

Anderson, R. S. (1987). Polykaryon formation by Mercenaria mercenaria hemocytes. The Biological Bulletin, 172(2), 236-245.

Axiak, V., George, J. J., \& Moore, M. N. (1988). Petroleum hydrocarbons in the marine bivalve Venus verrucosa: accumulation and cellular responses. Marine Biology, 97(2), 225-230.

Axiak, V., \& George, J. J. (1987). Bioenergetic responses of the marine bivalve Venus verrucosa on long-term exposure to petroleum hydrocarbons. Marine Environmental Research, 23(1), 33-47.

Barron, M. G., Podrabsky, T., Ogle, S., \& Ricker, R. W. (1999). "Are aromatic hydrocarbons the primary determinant of petroleum toxicity to aquatic organisms?" Aquatic Toxicology, 46(3), 253-268.

Barron, M. G., Carls, M. G., Short, J. W., \& Rice, S. D. (2003). "Photo-enhanced toxicity of aqueous phase and chemically dispersed weathered Alaska North Slope crude oil to Pacific herring eggs and larvae". Environmental Toxicology and Chemistry, 22(3), 650-660.

Barszcz, C., Yevich, P.P., Brown, L.R., Yarborough, J.D. and Minchew, C. D. (1977): Chronic effects of three crude oils on oysters suspended in estuarine ponds. Journal of Environmental Pathology and Toxicology. 1: 879-895

Berthou, F., Balouet, G., Bodennec, G., \& Marchand, M. (1987). The occurrence of hydrocarbons and histopathological abnormalities in oysters for seven years following the wreck of the Amoco Cadiz in Brittany (France). Marine Environmental Research, 23(2), 103-133. 
622

623
Boesch, D (2014) Expert Report prepared on behalf of the United States (TREX-013183). U.S. v. BP Exploration \& Production et al. 12

Cajaraville, M., Díez, G., Larrea, P., Marigómez, J. A., \& Angulo, E. (1989a). Planimetric parameters of the digestive tubules of Mytilus edulis: A sensitive tool for monitoring petroleum hydrocarbon toxicity. Seminario Internacional do mexillon. Toxa, O Grove (Spain). 6-10 Nov 1989.

Cajaraville, M. P., Uranga, J. A., \& Angulo, E. (1992). Comparative effects of the water accommodated fraction of three oils on mussels-3. Quantitative histochemistry of enzymes related to the detoxication metabolism. Comparative Biochemistry and Physiology Part C: Comparative Pharmacology, 103(2), 369377.

Calabrese, A., MacInnes, J. R., Nelson, D. A., Greig, R. A., \& Yevich, P. P. (1984). Effects of long-term exposure to silver or copper on growth, bioaccumulation and histopathology in the blue mussel Mytilus edulis. Marine Environmental Research, 11(4), 253-274.

Capuzzo, J. M. (1996). "The bioaccumulation and biological effects of lipophilic organic contaminants.” The Eastern Oyster Crassostrea virginica.MD Sea Grant Publication: 539-557

Carls, M. G., Holland, L., Larsen, M., Collier, T. K., Scholz, N. L., \& Incardona, J. P. (2008). Fish embryos are damaged by dissolved PAHs, not oil particles. Aquatic toxicology, 88(2), 121-127.

Carriger, J., and Barron, M.G. (2011). Minimizing risks from spilled oil to ecosystem services using influence diagrams: The Deepwater Horizon spill response. Environmental Science \& Technology 45, 7631-7639

Coen, L. D., Brumbaugh, R. D., Bushek, D., Grizzle, R., Luckenbach, M. W., Posey, M. H., Powers, S. P., \& Tolley, S. (2007). Ecosystem services related to oyster restoration. Marine Ecology Progress Series, 341, 303307.

Coughlan, J. (1969). The estimation of filtering rate from the clearance of suspensions. Marine Biology, 2 , 356-358

Di Giulio, R. T., Washburn, P. C., Wenning, R. J., Winston, G. W., \& Jewell, C. S. (1989). Biochemical responses in aquatic animals: a review of determinants of oxidative stress. Environmental Toxicology and Chemistry, 8(12), 1103-1123.

Domingos, F. V., Azevedo, M., Silva, M. D., Randi, M. A. F., Freire, C. A., de Assis, H. S., \& Ribeiro, C. O. (2007). Multibiomarker assessment of three Brazilian estuaries using oysters as bioindicators. Environmental research, 105(3), 350-363.

Donkin, P., and Widdows, J. (1990). Quantitative structure-activity relationships in aquatic invertebrate toxicology. Reviews in Aquatic Sciences, 2(3, 4), 375-398.

Dorland, W. A. N. (2011). Dorland's Illustrated Medical Dictionary32: Dorland's Illustrated Medical Dictionary. Elsevier Health Sciences.

Downs, C. A., Shigenaka, G., Fauth, J. E., Robinson, C. E., \& Huang, A. (2002). Cellular physiological assessment of bivalves after chronic exposure to spilled Exxon Valdez crude oil using a novel molecular diagnostic biotechnology. Environmental Science \& Technology, 36(13), 2987-2993.

Environmental Response Management Application (2015). Deepwater Gulf response. National oceanic and atmospheric administration. Available: http://response.restoration.noaa.gov/maps-and-spatialdata/environmental-response-management-application-erma/erma-gulf-response.html (accessed 7/30/2015) 
Lee, R. F., Gardner, W. S., Anderson, J. W., Blaylock, J. W., \& Barwell-Clarke, J. (1978). Fate of polycyclic aromatic hydrocarbons in controlled ecosystem enclosures. Environmental Science \& Technology, 12(7), 832838.

Farrington, J. W., Goldberg, E. D., Risebrough, R. W., Martin, J. H., \& Bowen, V. T. (1983). US" Mussel Watch" 1976-1978: an overview of the trace-metal, DDE, PCB, hydrocarbon and artificial radionuclide data. Environmental Science \& Technology, 17(8), 490-496.

Feng, S. Y. (1966). Experimental bacterial infections in the oyster Crassostrea virginica. Journal of Invertebrate Pathology, 8(4), 505-511.

Fisher, W. S., \& Tamplin, M. (1988). Environmental influence on activities and foreign-particle binding by hemocytes of American oysters, Crassostrea virginica. Canadian Journal of Fisheries and Aquatic Sciences, 45(7), 1309-1315.

Forth, H. P., Mitchelmore, C. L., Morris, J. M., Lay, C. R. and Lipton, J. (2017). Characterization of dissolved and particulate phases of water accommodated fractions used to conduct aquatic toxicity testing in support of the Deepwater Horizon natural resource damage assessment. Environmental Toxicolology \& Chemistry, 36: 1460-1472. doi:10.1002/etc.3803

Gainey, L. F., \& Shumway, S. E. (1991). The physiological effect of Aureococcus anophagefferens (" brown tide") on the lateral cilia of bivalve mollusks. The Biological Bulletin, 181(2), 298-306.

Galimany, E., Sunila, I., Hégaret, H., Ramón, M., \& Wikfors, G. H. (2008a). Experimental exposure of the blue mussel (Mytilus edulis) to the toxic dinoflagellate, Alexandrium fundyense: Histopathology, immune responses, and recovery. Harmful Algae, 7(5), 702-711.

Galtsoff, P. S., Prytherch, H. F., Smith, R. O., \& Koehring, V. (1935). Effects of crude oil pollution on oysters in Louisiana waters. US Government Printing Office.

Gilewicz, M., Guillaume, J. R., Carles, D., Leveau, M., \& Bertrand, J. C. (1984). Effects of petroleum hydrocarbons on the cytochrome P450 content of the mollusk bivalve Mytilus galloprovincialis. Marine biology, 80(2), 155-159.

Graham, W. M., Condon, R. H., Carmichael, R. H., D’Ambra, I., Patterson, H. K., Linn, L. J., \& Hernandez Jr, F. J. (2010). Oil carbon entered the coastal planktonic food web during the Deepwater Horizon oil spill. Environmental Research Letters, 5(4), 045301.

Hansen, B. H., Altin, D., Olsen, A. J., \& Nordtug, T. (2012). Acute toxicity of naturally and chemically dispersed oil on the filter-feeding copepod Calanus finmarchicus. Ecotoxicology and environmental safety, 86, $38-46$.

Hawthorne, S. B., Miller, D. J., \& Kreitinger, J. P. (2006). Measurement of total polycyclic aromatic hydrocarbon concentrations in sediments and toxic units used for estimating risk to benthic invertebrates at manufactured gas plant sites. Environmental toxicology and chemistry, 25(1), 287-296.

Howard, D.W., Lewis, E. J., Keller, B. J., and Smith, C. S. (2004). Histological techniques for marine bivalve mollusks and crustaceans. NOAA Technical Memorandum NOS NCCOS 5, 218 pp.

Huerta, L., López-Balderas, N., Rivera-Toledo, E., Sandoval, G., Gr̈mez-Icazbalceta, G., Villarreal, C., \& Larralde, C. (2009). HIV-Envelope-Dependent Cell-Cell Fusion: Quantitative Studies. The Scientific World Journal,9, 746-763.

Kim, Y., Ashton-Alcox, K.A., Powell, E.N., (2006). Histological techniques for marine bivalve molluscs: update. Silver Spring, MD, NOAA/National Centers for Coastal Ocean Science, 64pp. (NOAA Technical Memorandum NOS NCCOS, 27) 
Lewis, M. R., \& Lewis, W. H. (1926). Transformation of Mononuclear Blood-Cells Into Macrophages, Epithelioid Cells, and Giant-Cells in Hanging-Drop Blood-Cultures from Lower Vertebrates. Carnegie Institution.

Livingstone, D. R., Garcia Martinez, P., \& Winston, G. W. (1989). Menadione-stimulated oxyradical formation in digestive gland musomes of the common mussel, Mytilus edulis L. Aquatic Toxicology, 15(3), 213-236.

Livingstone, D. R. (2001). Contaminant-stimulated reactive oxygen species production and oxidative damage in aquatic organisms. Marine Pollution Bulletin, 42(8), 656-666.

Lowe, D. M., Moore, M. N., \& Clarke, K. R. (1981). Effects of oil on digestive cells in mussels: quantitative alterations in cellular and lysosomal structure. Aquatic Toxicology, 1(3), 213-226.

Luna-Acosta, A., Kanan, R., Le Floch, S., Huet, V., Pineau, P., Bustamante, P., \& Thomas-Guyon, H. (2011). Enhanced immunological and detoxification responses in Pacific oysters, Crassostrea gigas, exposed to chemically dispersed oil. Water research, 45(14), 4103-4118.

Luna-Acosta, A., Bustamante, P., Thomas-Guyon, H., Zaldibar, B., Izagirre, U., \& Marigómez, I. (2017). Integrative biomarker assessment of the effects of chemically and mechanically dispersed crude oil in Pacific oysters, Crassostrea gigas. Science of The Total Environment, 598, 713-721.

Mariano, M., \& Spector, W. G. (1974). The formation and properties of macrophage polykaryons (inflammatory giant cells). The Journal of pathology, 113(1), 1-19.

Moore, M. N. (1985). Cellular responses to pollutants. Marine Pollution Bulletin, 16(4), 134-139.

Morton, B. S. (1977). The tidal rhythm of feeding and digestion in the pacific oyster, Crassostrea gigas (Thunberg). Journal of Experimental Marine Biology and Ecology, 26(2), 135-151.

National Commission on the BP Deepwater Horizon oil spill and offshore drilling. (2010). Stopping the spill: The five-month effort to kill the Macondo well. Draft. Staff working Paper No. 6. November 22. Available: http://permanent.access.gpo.gov/gpo2428/Containment\%20Working\%20Paper\% 2011\%2022\%2010.pdf. Accessed July 7, 2015.

National Marine Fisheries Service, NMFS (2012). Annual Commercial Landing Statistics, Fisheries Statistics. Available at http://www.st.nmfs.noaa.gov/st1/commercial/landings/annual landings.html (last consulted in July 2014)

National Research Council, NRC (2003). Oil in the Sea III: Inputs, Fates, and Effects. National Academy Press, Washington, DC.http://dx.doi.org/10.17226/10388

Neff, J. M., \& Anderson, J. W. (1981). Response of marine animals to petroleum and specific petroleum hydrocarbons. Applied Science Pub. Halsted Press, New York, NY, U.S.A.

Neff, J. M., \& Haensly, W. E. (1982). Long-term impact of the Amoco Cadiz crude oil spill on oysters Crassostrea gigas and plaice Pleuronectes platessa from Aber Benoit and Aber Wrac'h, Brittany, France. Ecological Study of the AMOCO Cadiz Oil Spill October 1982. pp 269-327,

Neff, J. M. (1985). "Polycyclic aromatic hydrocarbons." Fundamentals of Aquatic Toxicology: Methods and Applications. Hemisphere Publishing Corporation Washington DC. 1985. pp 416-454.

Neff, J. M., \& Stubblefield, W. A. (1995). Chemical and toxicological evaluation of water quality following the Exxon Valdez oil spill. ASTM Special Technical Publication, (1219), 141-177.

Newell, R. I. (2004). Ecosystem influences of natural and cultivated populations of suspension-feeding bivalve molluscs: A review. Journal of Shellfish Research. 23(1), 51-62. 
Nixon, Z., Zengel, S., \& Michel, J. NOAA Technical Report: Categorization of Shoreline Oiling from the Deepwater Horizon Oil Spill. (September 1, 2015) https://pub-dwhdatadiver.orr.noaa.gov/dwh-ardocuments/901/DWH-AR0270684.pdf

O'Connor, T. P., \& Lauenstein, G. G. (2006). Trends in chemical concentrations in mussels and oysters collected along the US coast: update to 2003. Marine Environmental Research, 62(4), 261-285.

Owen, G. (1973). Feeding and digestion in the bivalvia. Advances in comparative physiology and biochemistry, 5, 1-35.

Pelletier, M. C., Burgess, R. M., Ho, K. T., Kuhn, A., McKinney, R. A. \& Ryba, S. A. (1997). Phototoxicity of individual Polycyclic Aromatic Hydrocarbons and petroleum to marine invertebrate larvae and juveniles. Environmental Toxicology and Chemistry, 16(10), 2100-2199.

Powers, S. P., Grabowski, J. H, Roman, H., Geggel, A., Rouhani, S., Oehrig, J., \& Baker, M. (2015). Consequences of large scale hydrographic alteration during the Deepwater Horizon Oil Spill on subtidal oyster populations. Technical report, September 9, 2015. DWH-AR0270347

Sami, S., Faisal, M., \& Huggett, R. J. (1992). Alterations in cytometric characteristics of hemocytes from the American oyster Crassostrea virginica exposed to a polycyclic aromatic hydrocarbon (PAH) contaminated environment. Marine Biology, 113(2), 247-252.

Supan, J. (1983). Evaluation of a leased oyster bottom in Mississippi Sound. Gulf Research Reports, 7(3), 261-266.

U.S. District Court. 2014. In re: Oil Spill by the Oil Rig "Deepwater Horizon" in the Gulf of Mexico, on April 20, 2010, No. MDL 2179, Section 7 (Revised September 9, 2014) ("Findings of Fact and Conclusions of Law: Phase One Trial"), Figure 1. United States District Court for the Eastern District of Louisiana.

U.S. District Court. (2015). In re: Oil Spill by the Oil Rig "Deepwater Horizon" in the Gulf of Mexico, on April 20, 2010, No. MDL 2179, 2015 WL 225421 (La. E.D. Jan. 15, 2015) ("Findings of Fact and Conclusions of Law: Phase Two Trial"). United States District Court for the Eastern District of Louisiana.

US Environmental Protection Agency (1986). SW-846 Manual for waste testing, Vol. 1B and 1C. Washington, DC, 8270D 1-72.

Vignier, J., Donaghy, L., Soudant, P., Chu, F.L.E, Morris, J.M., Carney, M.W., Lay, C., Krasnec, M., Robert, R., \& Volety, A.K., (2015). Impacts of Deepwater Horizon oil and associated dispersant on early development of the Eastern oyster, Crassostrea virginica. Marine Pollution Bulletin, 100, 426-437.

http://dx.doi.org/10.1016/i.marpolbul.2015.08.011.

Vignier, J., Soudant, P., Chu, F.L.E, Morris, J.M., Carney, Lay, C., Krasnec, M.O., Robert, R., \& Volety, A.K., (2016). Lethal and sublethal effects of Deepwater Horizon slick oil and dispersant on oyster (Crassostrea virginica) larvae. Marine Environmental Research 120, 20-31.

Wells, H.W. (1961). The fauna of oyster beds, with special reference to the salinity factor. Ecological Monographs. 31(3), 239-266.

Widdows, J., Bakke, T., Bayne, B. L., Donkin, P., Livingstone, D. R., Lowe, D. M, Moore, M. N., Evans, S. V. \& Moore, S. L. (1982). Responses of Mytilus edulis on exposure to the water-accommodated fraction of North Sea oil. Marine Biology, 67(1), 15-31.

Wikfors, G. H., \& Smolowitz, R. M. (1995). Experimental and histological studies of four life-history stages of the eastern oyster, Crassostrea virginica, exposed to a cultured strain of the dinoflagellate Prorocentrum minimum. The Biological Bulletin, 188(3), 313-328. 
821

822

826

6

Winstead, J. T. (1995). Digestive tubule atrophy in eastern oysters, Crassostrea virginica (Gmelin, 1791), exposed to salinity and starvation stress. Journal of Shellfish Research, 14(1), 105-112.

Yamuna, A., Kabila, V., \& Geraldine, P. (1996). Biochemical and histological alterations in the prawn Macrobrachium lamerrei following exposure to automobile discharge. GeoJournal, 40(1-2), 233-237.

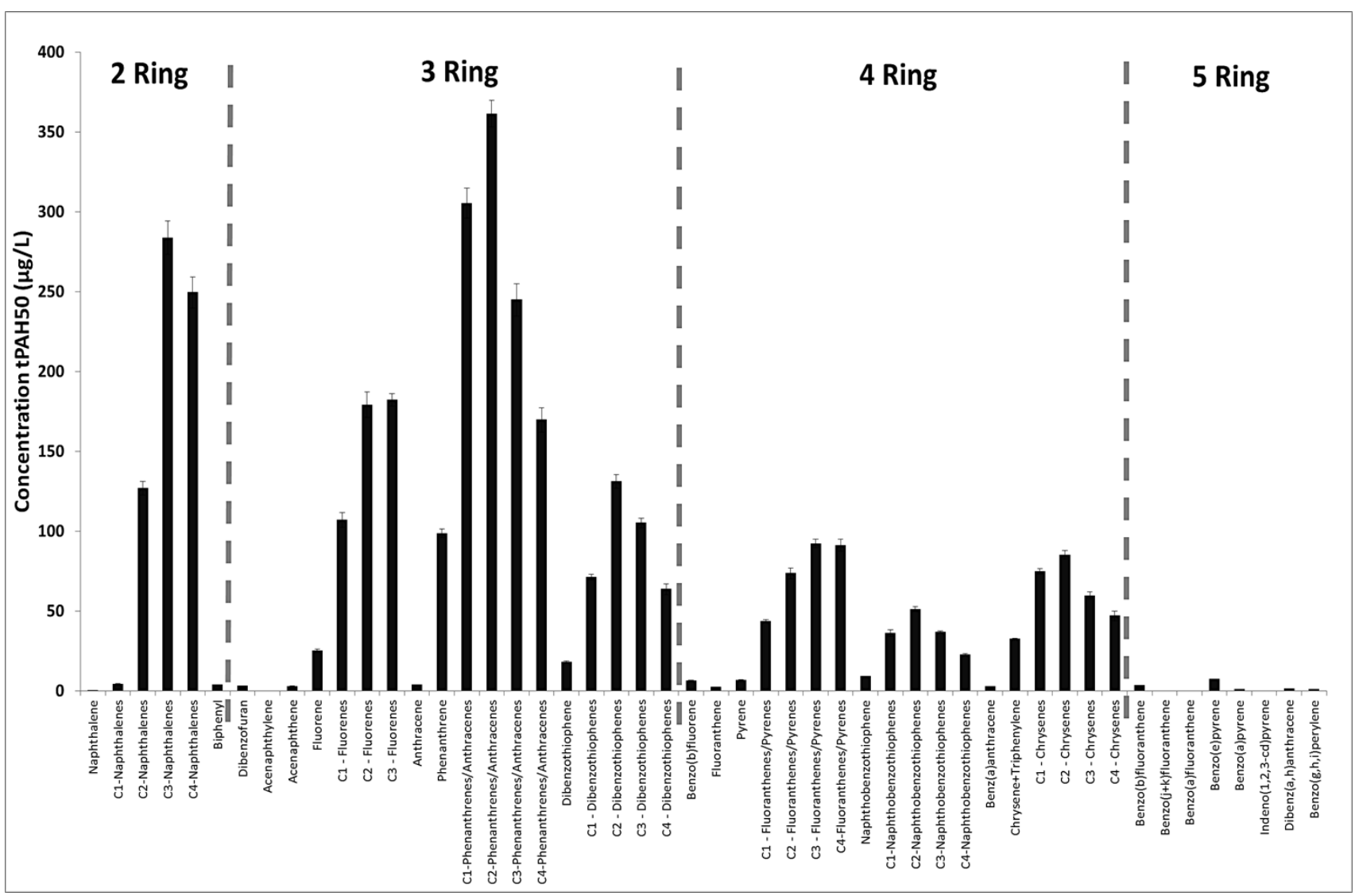

Supplementary file: Initial concentrations, expressed in $\mu \mathrm{g} \mathrm{L}^{-1}$, for the $50 \mathrm{PAH}$ analytes (parent and alkyl 830 day-exposure of oyster spat. Generalized subclasses are divided by dotted lines and noted on the figure 

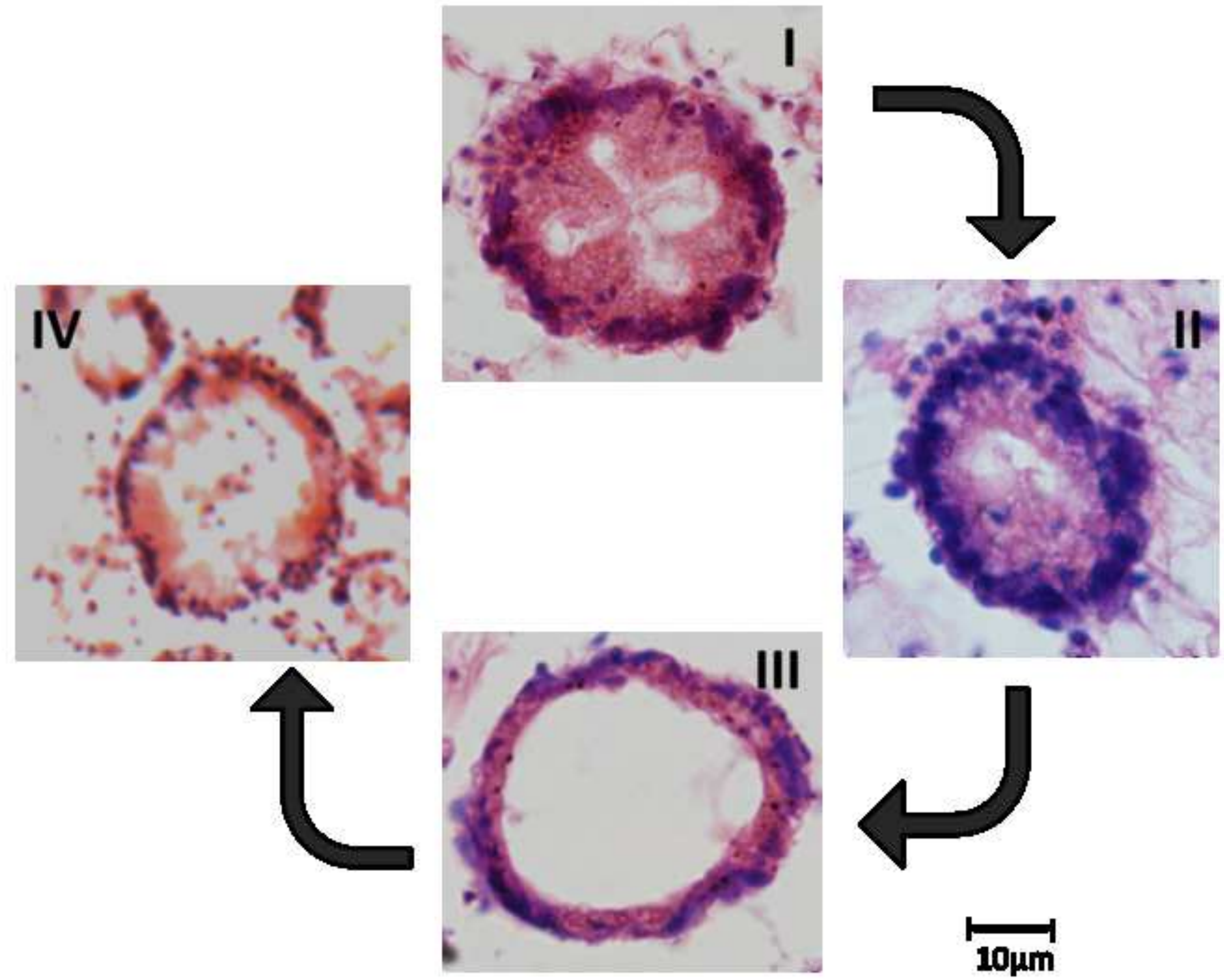


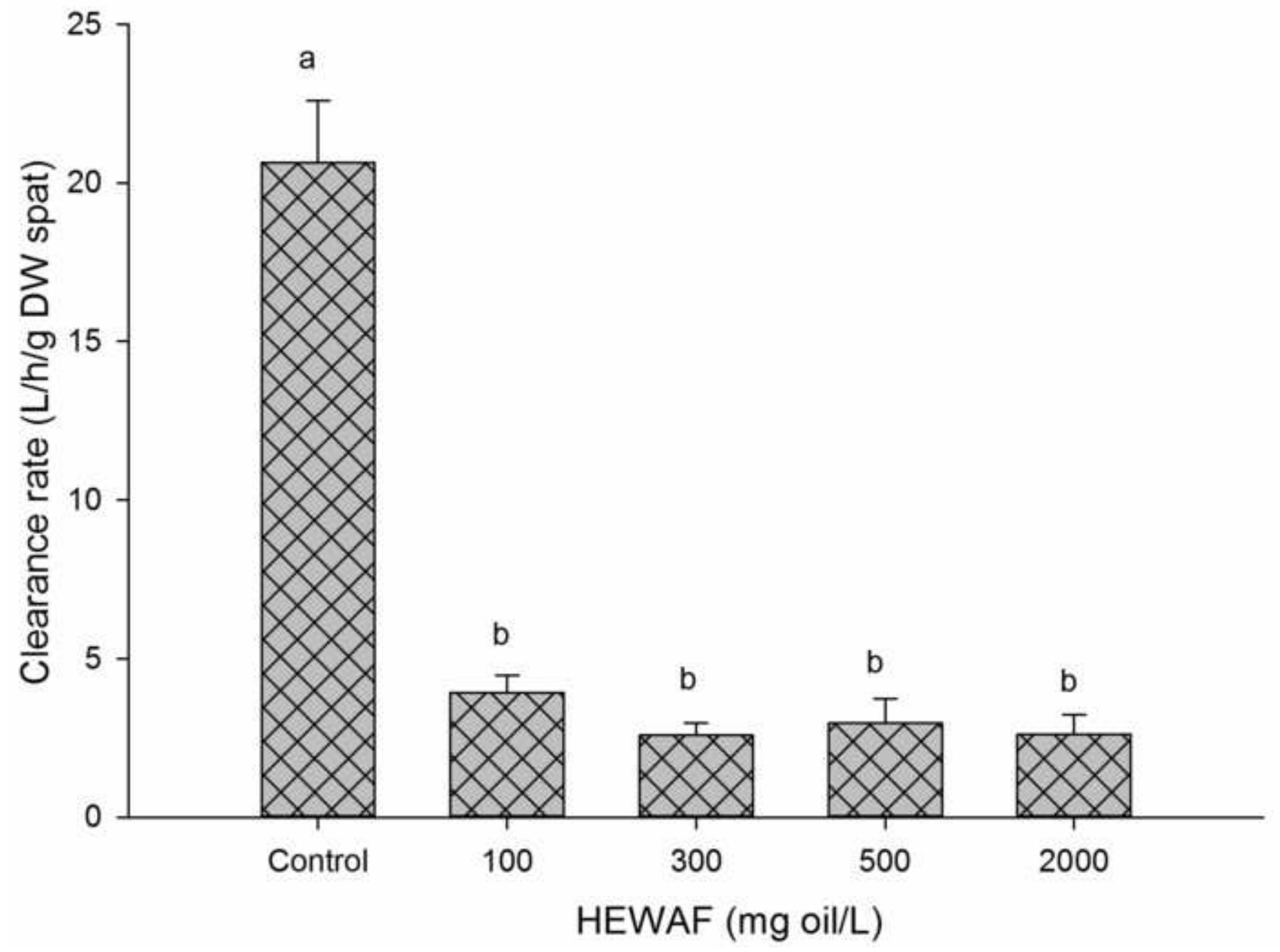




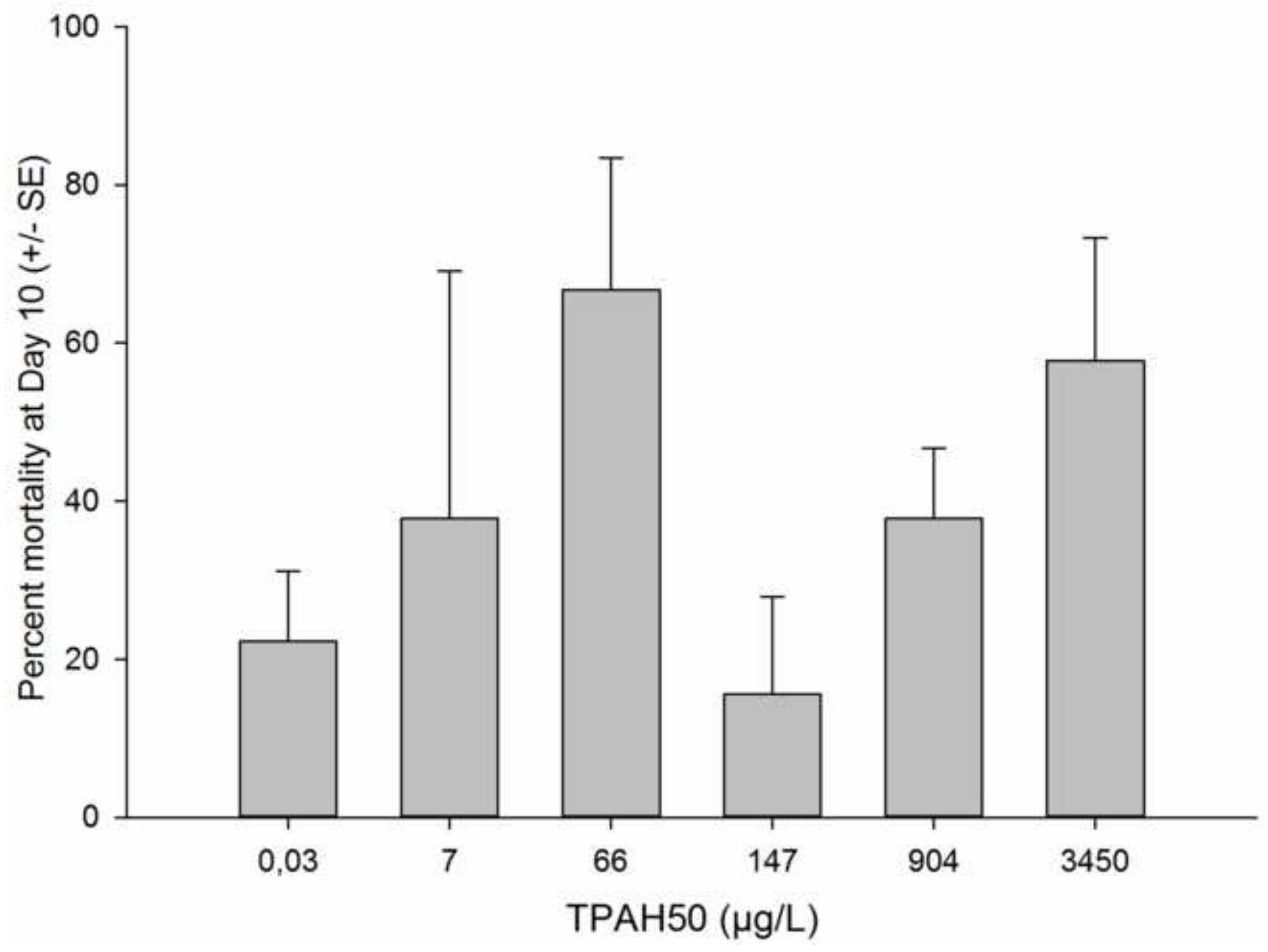




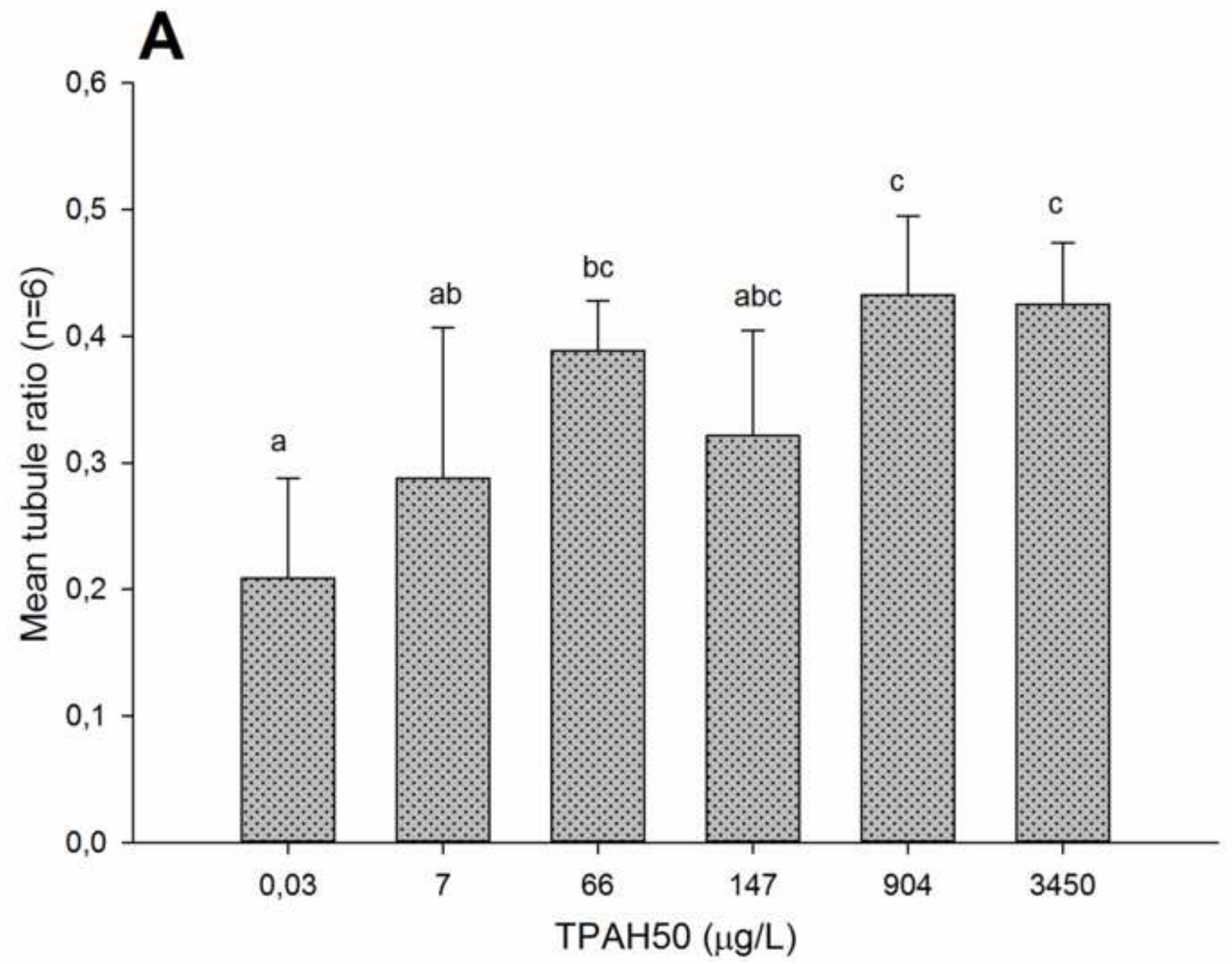




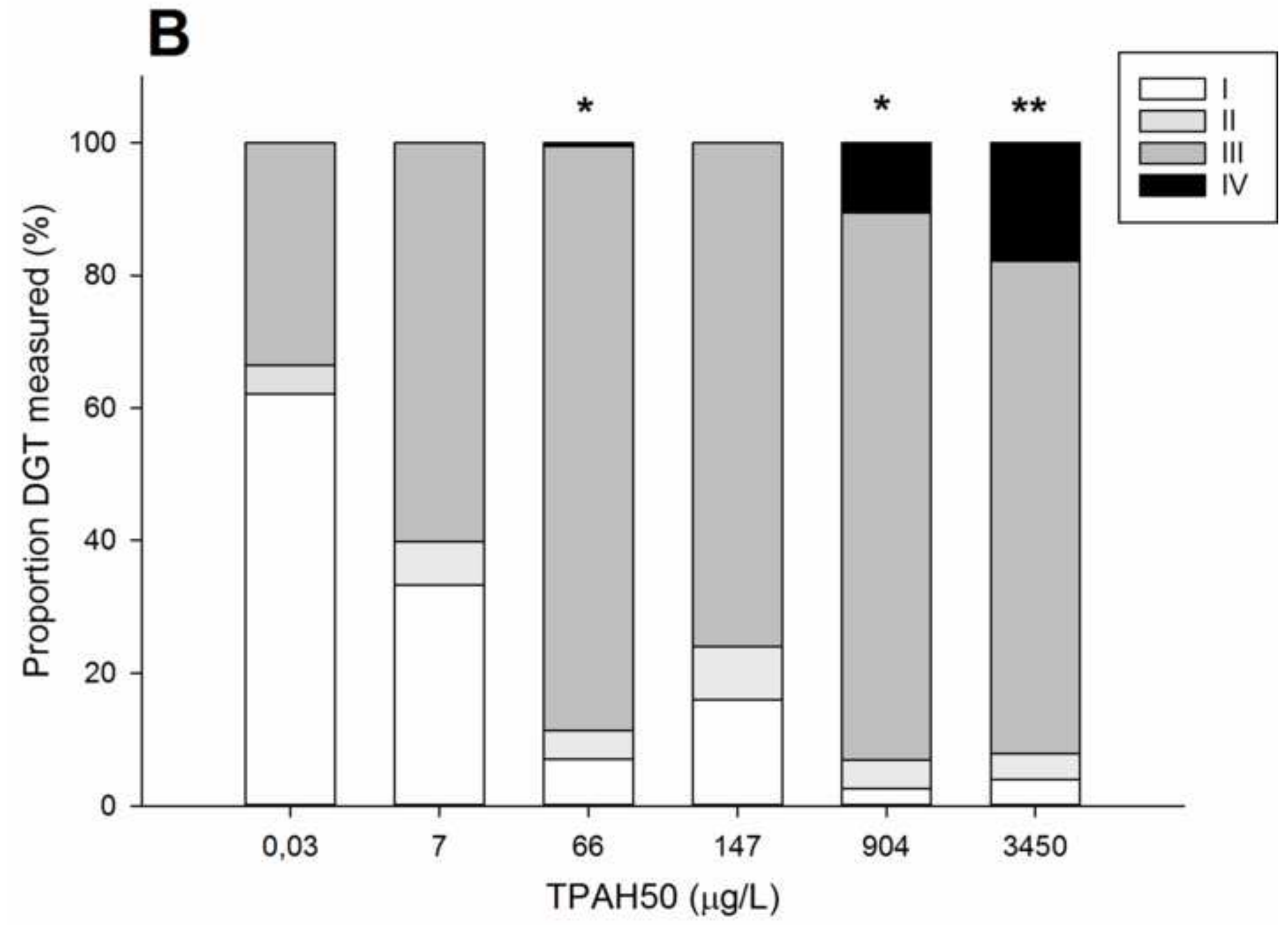




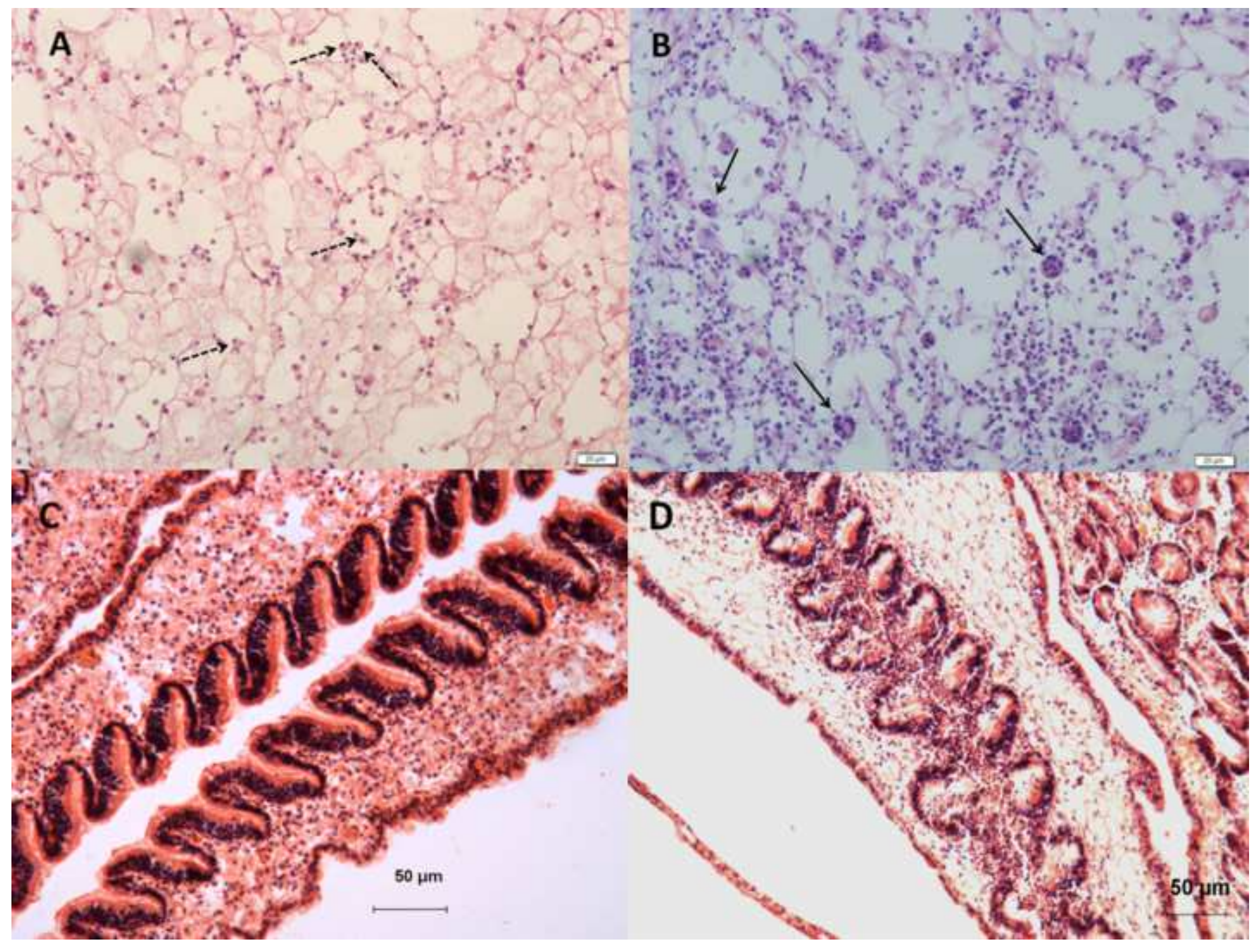




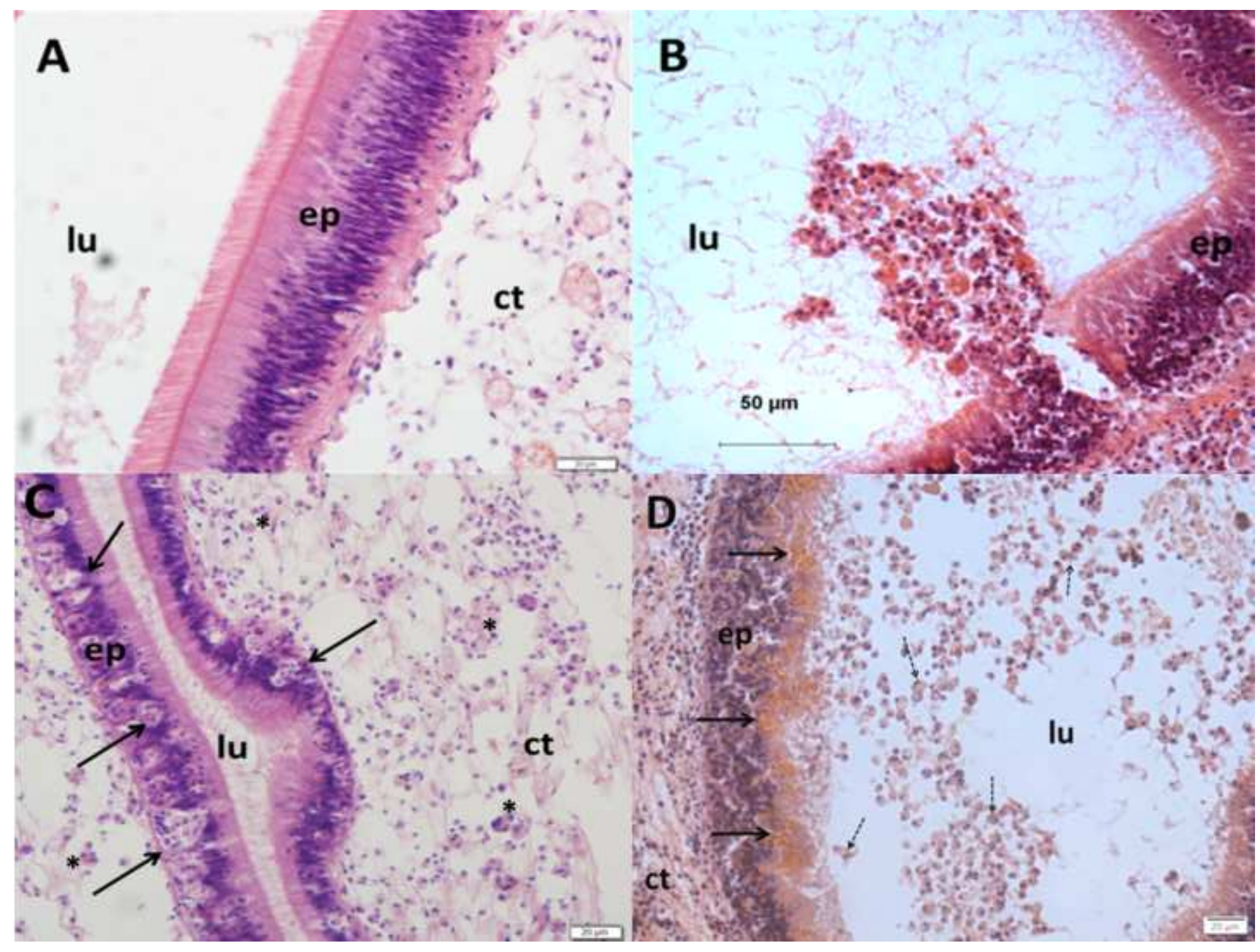




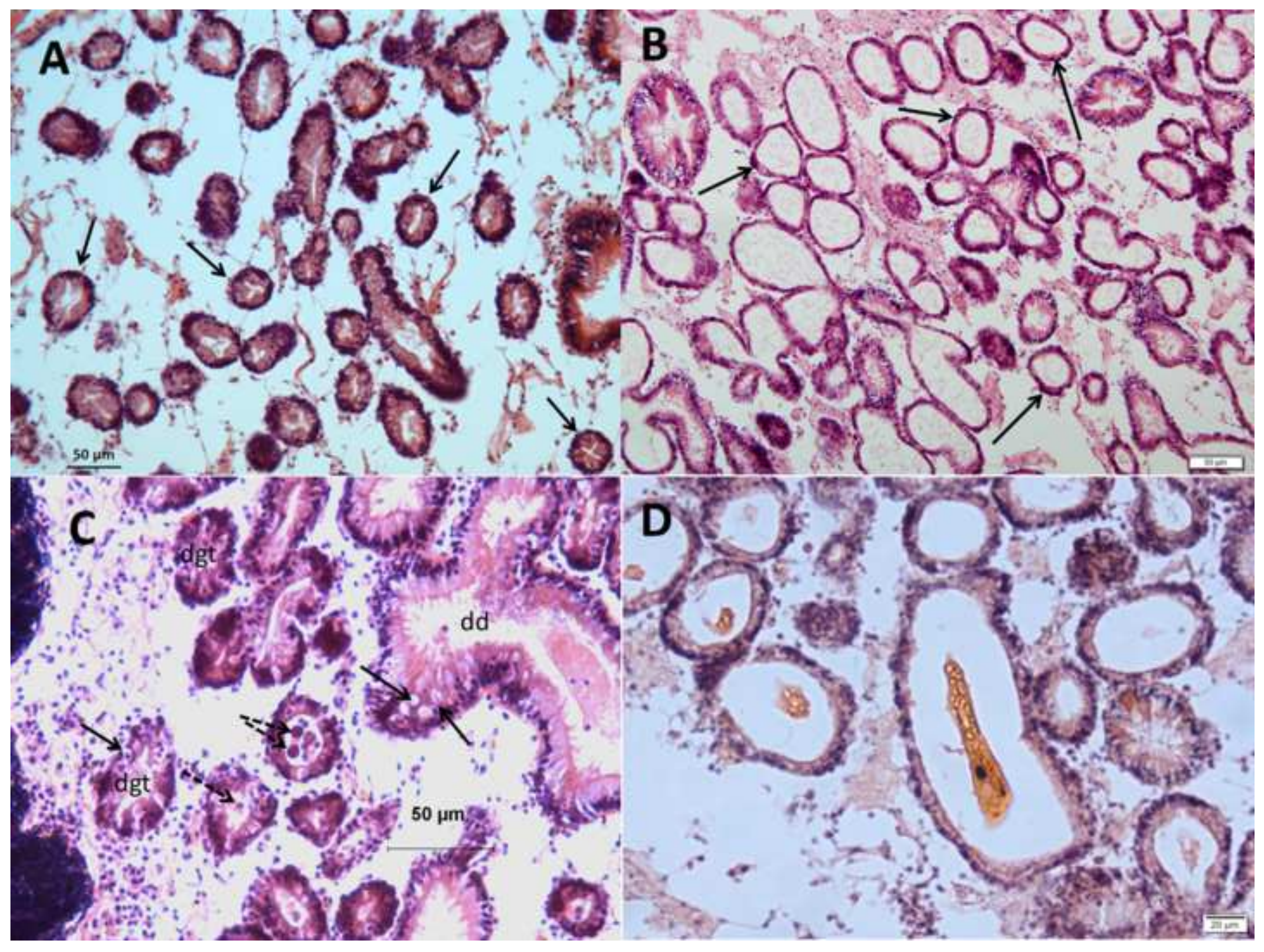




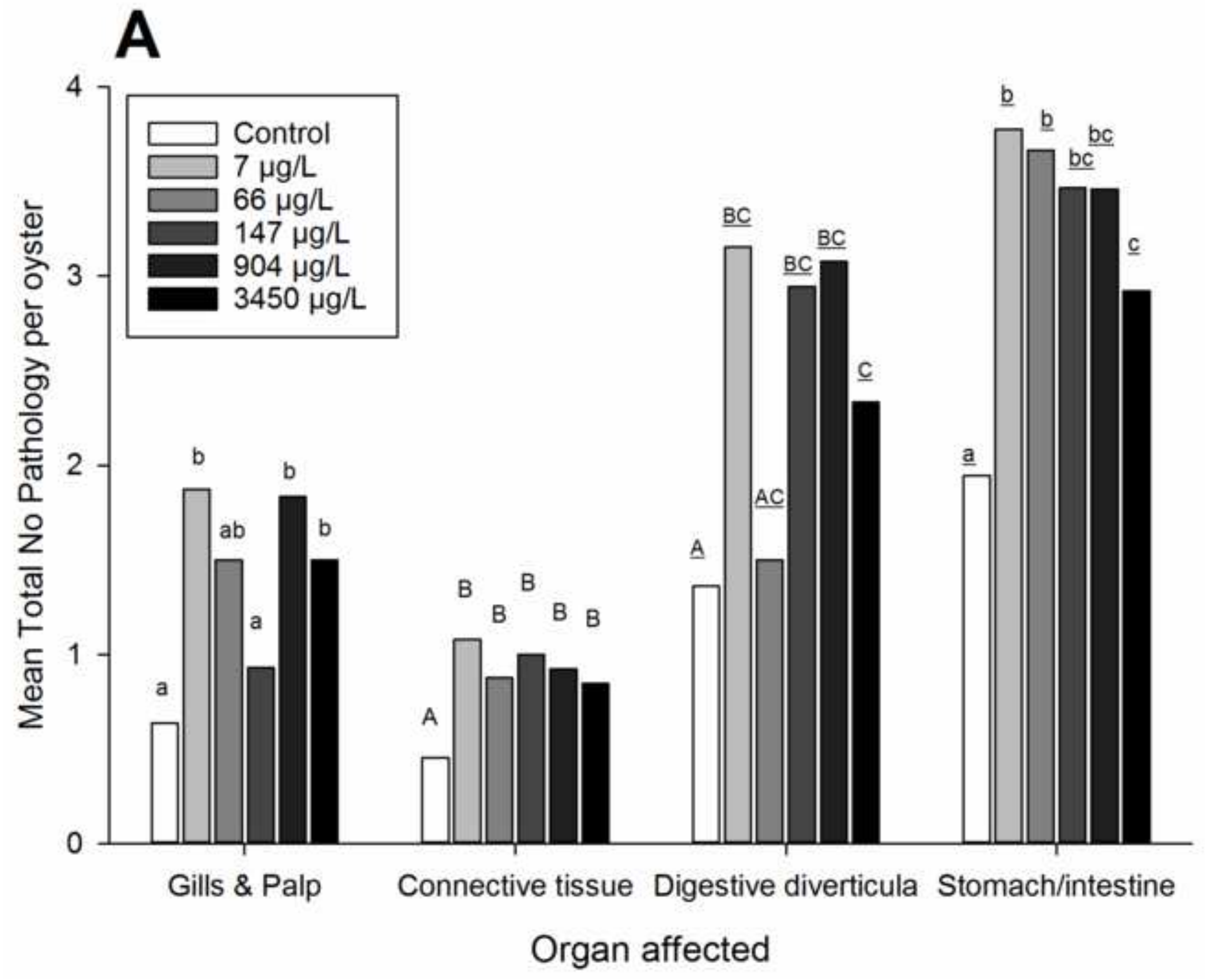




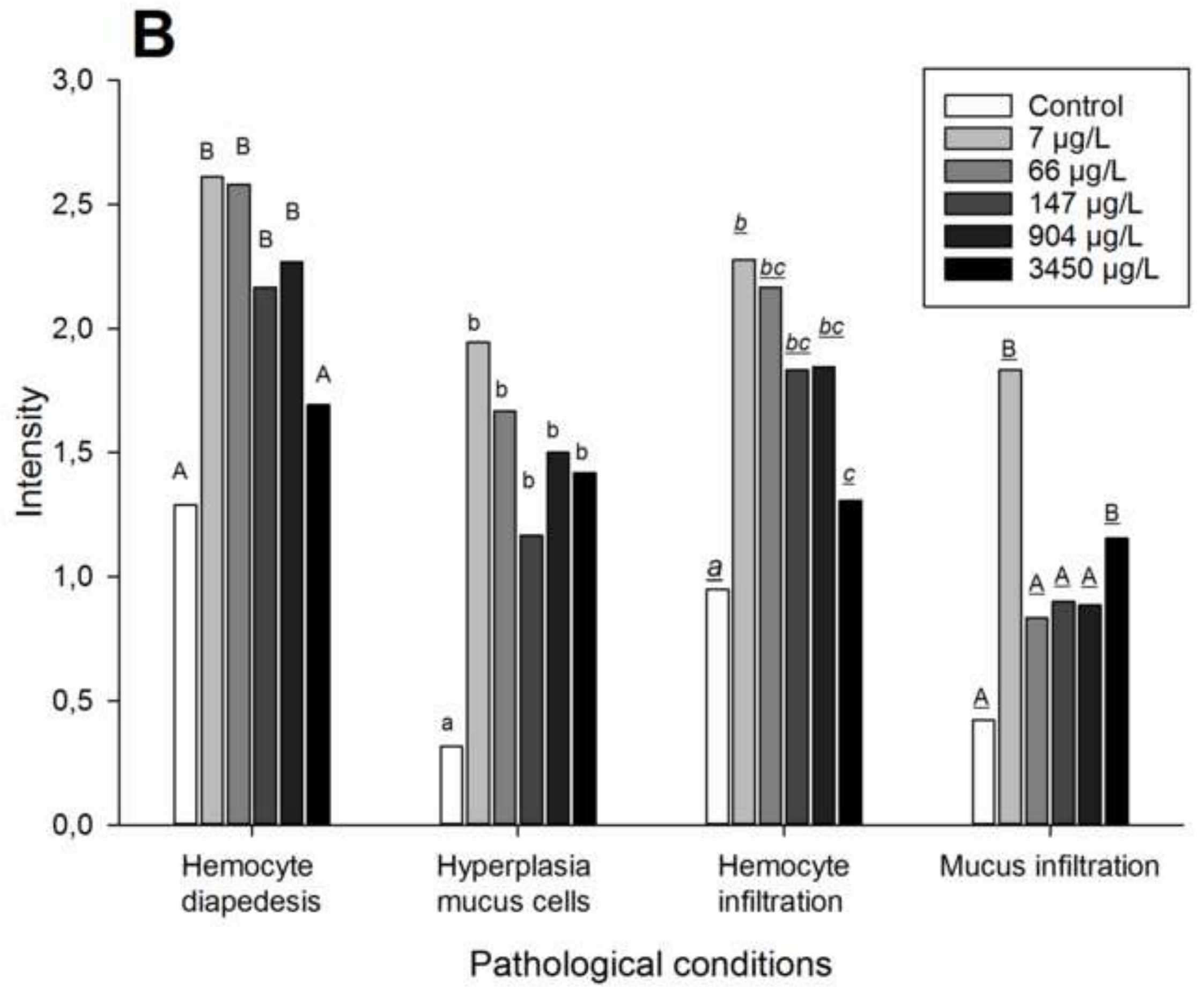




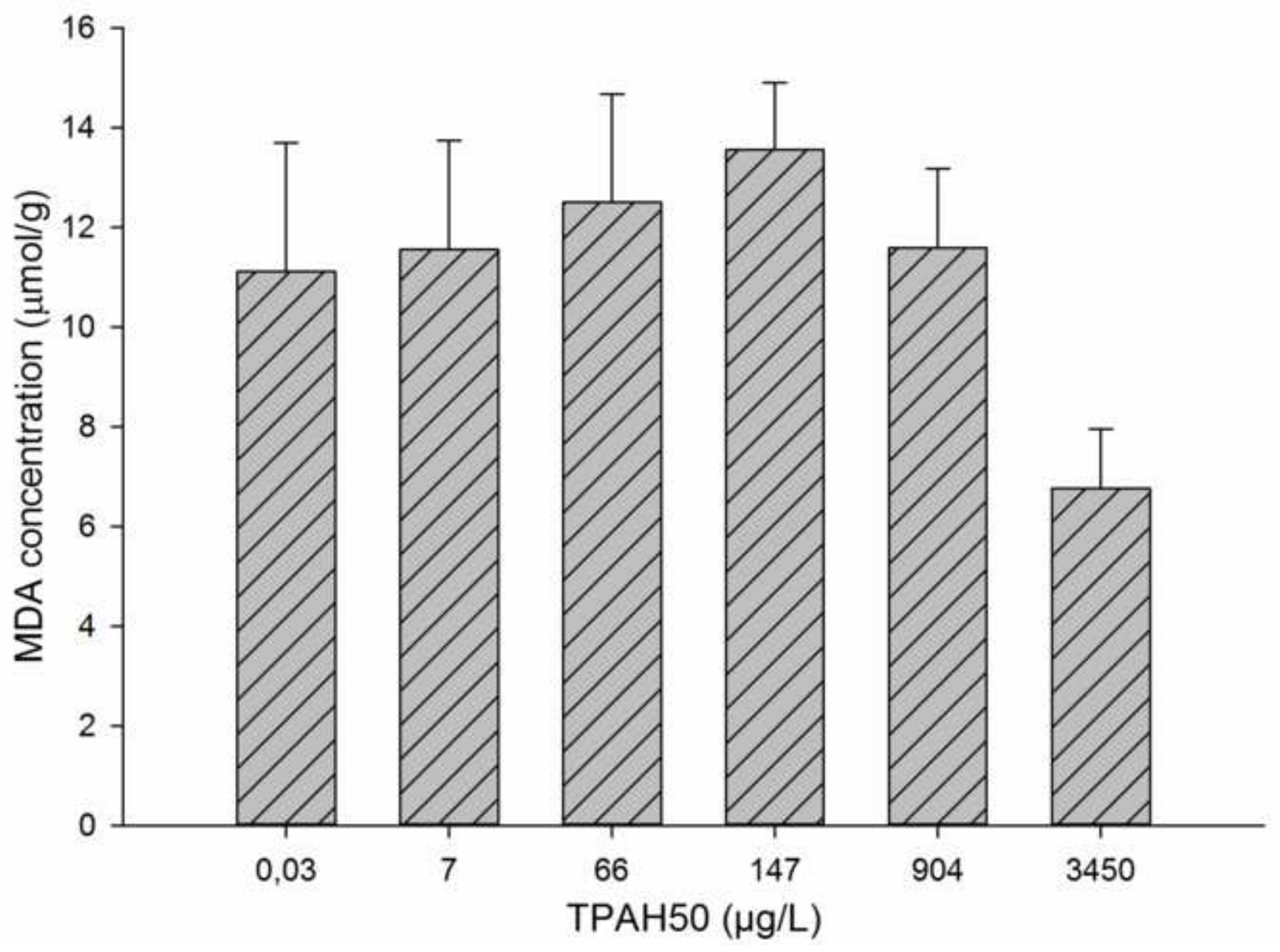


Click here to access/download Supplementary Material Supplementary File PAH profile stocks.tif 